\title{
Bull Trout Life History, Genetics, Habitat Needs, and Limiting Factors in Central and Northeast Oregon
}

Annual Report

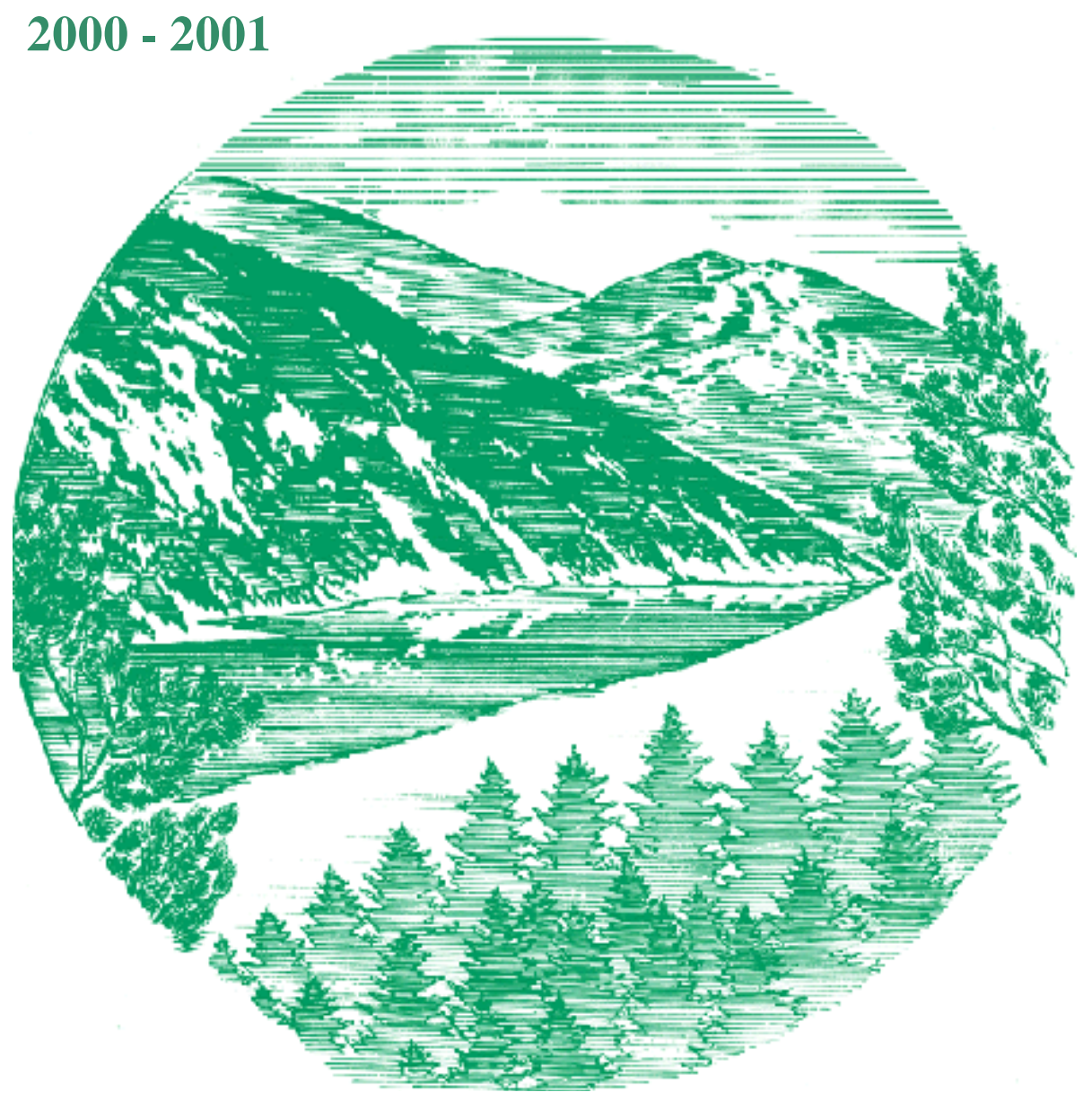

DOE/BP-00004101-1

December 2002 
This Document should be cited as follows:

Hemmingsen, Alan, Stephanie Gunckel, Paul Sankovich, Philip Howell, "Bull Trout Life

History, Genetics, Habitat Needs, and Limiting Factors in Central and Northeast Oregon",

Project No. 1994-05400, 34 electronic pages, (BPA Report DOE/BP-00004101-1)

\author{
Bonneville Power Administration \\ P.O. Box 3621 \\ Portland, Oregon 97208
}

This report was funded by the Bonneville Power Administration (BPA), U.S. Department of Energy, as part of BPA's program to protect, mitigate, and enhance fish and wildlife affected by the development and operation of hydroelectric facilities on the Columbia River and its tributaries. The views in this report are the author's and do not necessarily represent the views of BPA. 
BULL TROUT LIFE HISTORY, GENETICS, HABITAT NEEDS, AND LIMITING

FACTORS IN CENTRAL AND NORTHEAST OREGON

2001 ANNUAL REPORT

Prepared by:

Alan R. Hemmingsen

Stephanie L. Gunckel

Paul M. Sankovich

Oregon Department of Fish and Wildlife

Portland, OR

and

Philip J. Howell

USDA Forest Service

Pacific Northwest Research Station

La Grande, OR

Prepared for:

U.S. Department of Energy

Bonneville Power Administration

Environment, Fish and Wildlife

P.O. Box 3621

Portland, OR 97208-3621

Project Number 199405400

Contract Number $94 \mathrm{~B} 134342$

December 2002 


\section{Table of Contents}

I. Movement and life history of bull trout in the Walla Walla and

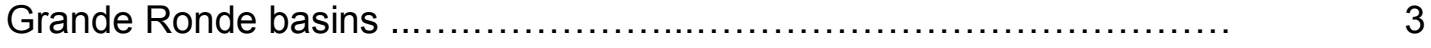

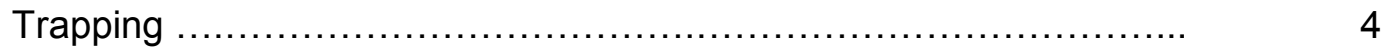

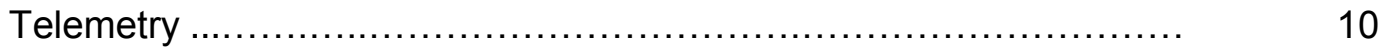

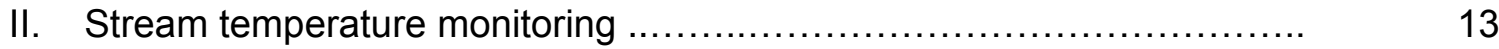

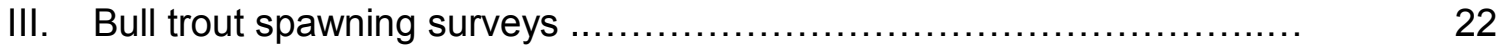

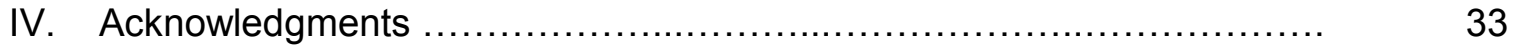

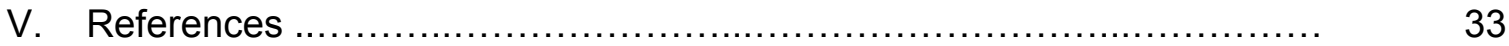




\section{Movement and life history of bull trout in the Walla Walla, John Day and Grande Ronde basins}

\section{Introduction}

Bull trout Salvelinus confluentus exhibit a number of life history strategies. Stream-resident bull trout complete their life cycle in their natal tributaries. Migratory bull trout spawn in tributary streams where juvenile fish usually spend from one to four years before migrating to either a larger river (fluvial) or lake (adfluvial) where they rear before returning to the tributary stream to spawn (Fraley and Shepard 1989). These migratory forms occur where conditions allow movement from spawning locations to downstream waters that provide greater foraging opportunities (Dunham and Rieman 1999). Resident and migratory forms may occur together, and either form can produce resident or migratory offspring (Rieman and Mclntyre 1993). The ability to migrate is important to the persistence of local bull trout populations (Rieman and Mclntyre 1993). The identification of migratory corridors can help focus habitat protection efforts. Determining the life history form(s) that comprise local populations, the timing of seasonal movements, and the geographic extent of these movements are critical to bull trout protection and recovery efforts.

This section describes work accomplished in 2001 that continued to address two objectives of this project. These objectives are 1) determine the distribution of juvenile and adult bull trout and habitats associated with that distribution, and 2) determine fluvial and resident bull trout life history patterns. Completion of these objectives is intended through studies of bull trout in the Grande Ronde, Walla Walla, and John Day basins. These basins were selected because they provide a variety of habitats, from relatively degraded to pristine, and bull trout populations were thought to vary from relatively depressed to robust. In the Grande Ronde and Walla Walla basins, we continued to monitor the movements of bull trout with radio transmitters applied in 1998 (Hemmingsen, Bellerud, Gunckel and Howell 2001) and 1999 (Hemmingsen, Gunckel and Howell 2001). No new radio transmitters were applied to bull trout of the upper John Day River subbasin, Mill Creek (Walla Walla Basin), or the Grande Ronde Basin in 2001.

In Mill Creek, we used traps for the fourth consecutive year to obtain data on migrant bull trout. With these traps, we intended to determine the timing of bull trout movements both upstream and downstream, and to determine the relative abundance and size of migrant fish. No traps were operated in the John Day Basin in 2001.

\section{Methods}

In Mill Creek, we trapped upstream migrant bull trout as they exited the fish ladder at the dam (Rkm 40.9) associated with the water intake for the city of Walla Walla, as described in Hemmingsen, Bellerud, Gunckel and Howell (2001). These upstream migrant bull trout were trapped from the first week of June through mid-October. We operated a rotary screw trap (1.5-m diameter) from September 2001 through March 2002 in order to determine the timing and magnitude of the juvenile bull trout migration downstream during fall, winter, and early spring. In the three previous years, we had operated the screw trap from March through mid-October. Juvenile bull trout were captured during all months in each of these years (Hemmingsen, Bellerud, Gunckel and Howell 2001; Hemmingsen, Gunckel and Howell 2001; Hemmingsen, Gunckel, Sankovich and Howell 2001). Whether juveniles continued to migrate downstream, particularly in winter, remained unknown. The screw trap was located upstream of the dam at the same site (Rkm 42) used in 1998, 1999 , and 2000. 
In both traps, fish of most species captured were anesthetized and measured to fork length. All bull trout were weighed, and all but a few were measured. Scales were collected from a sub-sample of bull trout. Bull trout that were $150 \mathrm{~mm}$ fork length or longer were checked for the presence of a 14-mm, $125 \mathrm{KHz}$, Avid PIT (passive integrated transponder) tag applied during 1997 - 2000. Bull trout captured in 2001 that had not previously received PIT tags were subsequently implanted with them. These PIT tags had a frequency of $134 \mathrm{KHz}$, and their identification codes were scanned in the office prior to use in the field. Only $125-\mathrm{KHz}$ tags could be scanned in the field during 2001. A portion of the bull trout captured in the Mill Creek screw trap received a caudal fin mark to identify them for trap efficiency calculations. A maximum of $3 \mathrm{~mm}$ was cut from either the top or bottom lobe of the caudal fin. After recovering from anesthesia, these fish and others that were PIT-tagged were released in a pool $112 \mathrm{~m}$ upstream of the screw trap. Efficiency of the screw trap was determined monthly from the number of recaptured, fin-marked or PIT-tagged bull trout. Estimated numbers of bull trout that passed the screw trap were calculated by bootstrap methods.

\section{Results and discussion}

\section{$\underline{\text { Trapping }}$}

Bull trout captured by traps can be divided into two groups: those captured for the first time in each trap, or those recaptured one or more times in either trap. Recaptured individuals were identified by a fin mark or PIT tag. Figures presented here describe individuals captured for the first time in 2001 in either trap. Recaptured bull trout are discussed in the text or identified in tables.

The upstream migrant trap was installed on 05 June and checked daily all but two days until its removal on 15 October. During its operation, this trap captured 157 bull trout, of which 156 were measured with lengths ranging from 212 to $710 \mathrm{~mm}$, with a mean of $437 \mathrm{~mm}$ (Fig. 1). Only four bull trout $(2.6 \%)$ were less than $300 \mathrm{~mm}$, and two were less than $250 \mathrm{~mm}$. 

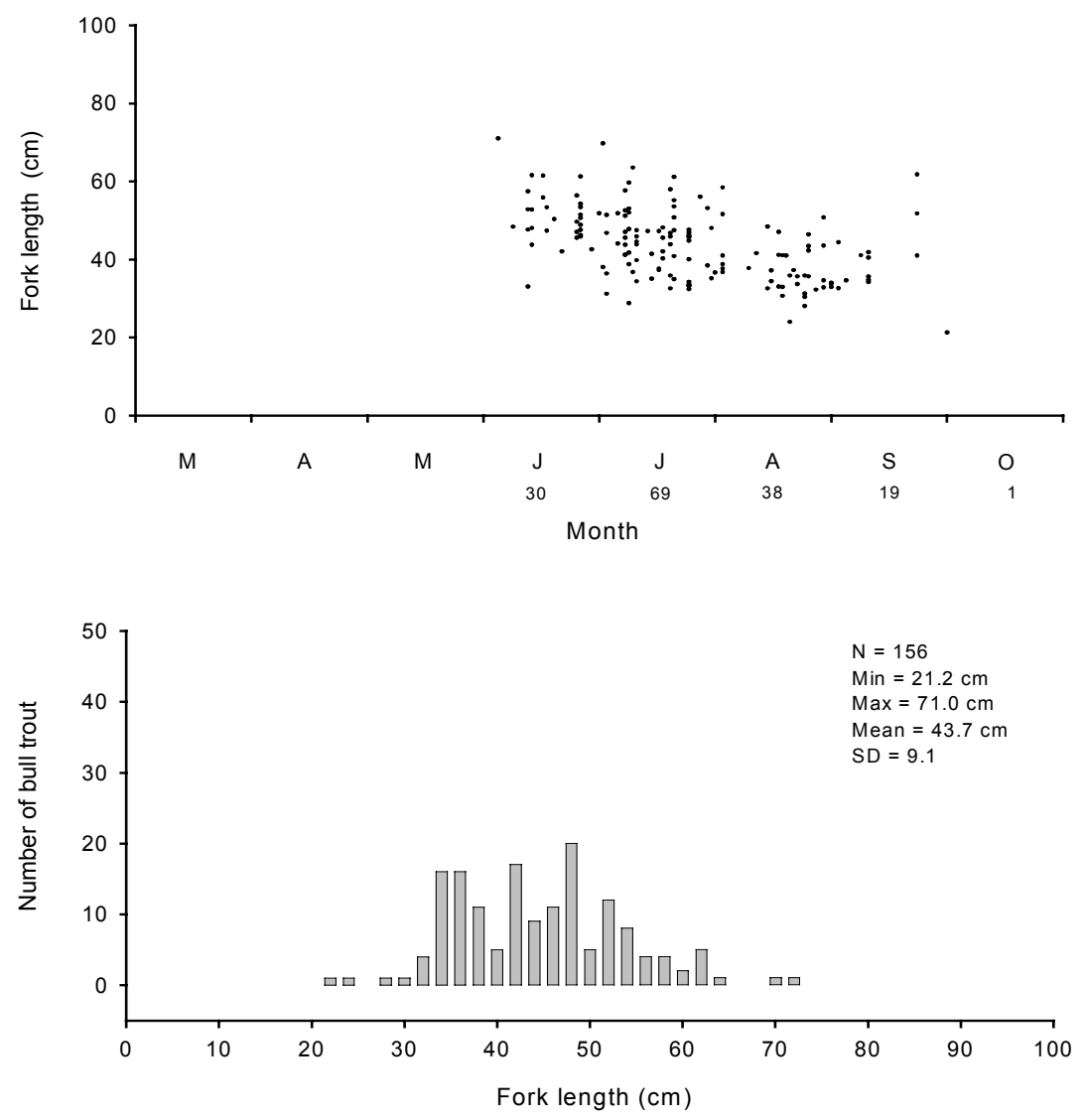

Figure 1. Numbers and lengths of bull trout in Mill Creek captured in the upstream migrant trap in 2001 . Monthly totals are shown under corresponding months.

Of the 156 measured bull trout, 106 had PIT tags that were applied in previous years. The remaining 50 bull trout that were PIT-tagged in 2001 tended to be smaller than those tagged previously (Fig 2). In addition to bull trout, this trap captured 25 juvenile Oncorhynchus tshawytscha, 10 O. mykiss (180-300 mm), 13 Catostomus spp (200-300 mm), and 3 Prosopium williamsoni (250$420 \mathrm{~mm})$. 


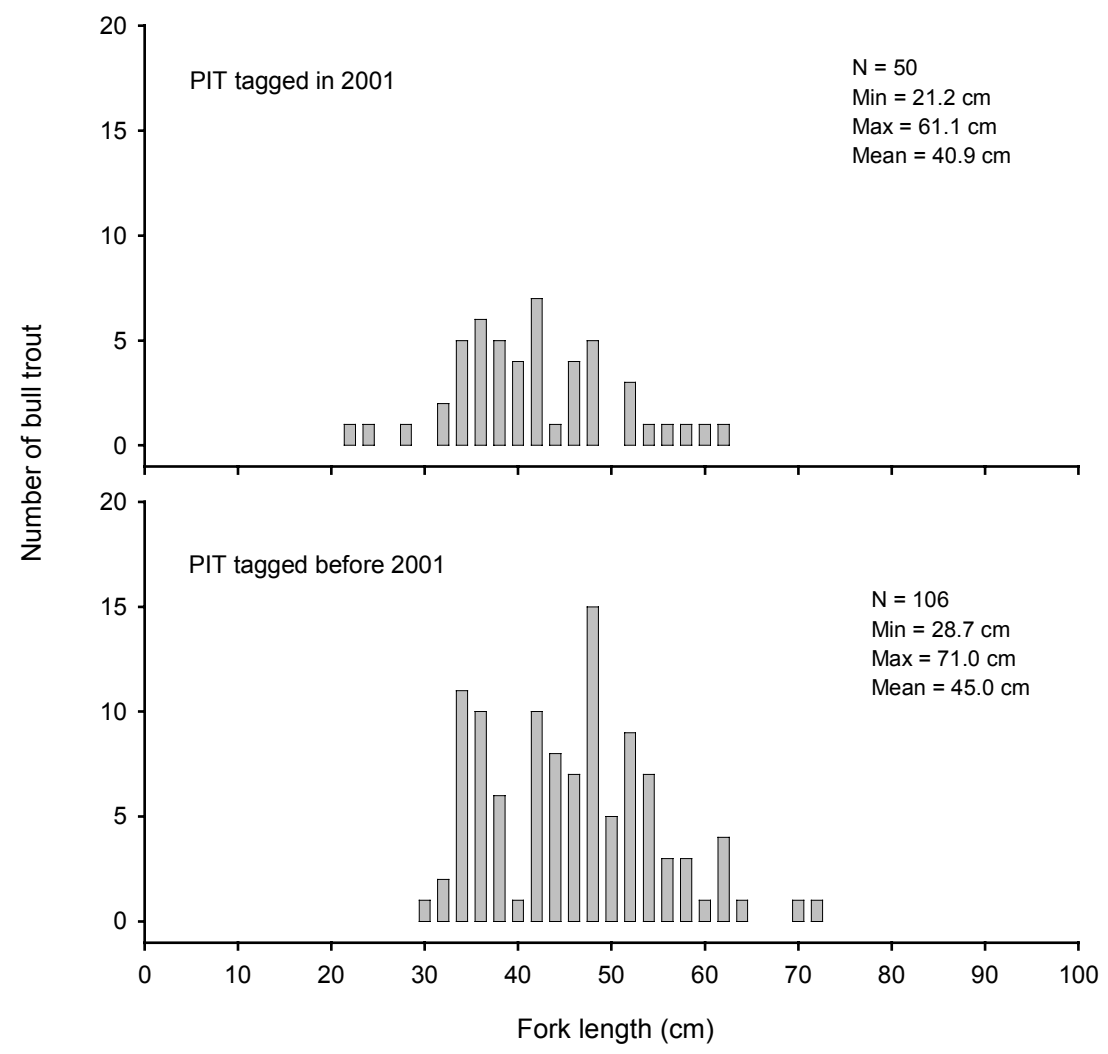

Figure 2. Numbers and lengths of bull trout in Mill Creek captured in the upstream migrant trap in 2001.

Sixty-three percent of the upstream migrant bull trout were captured by 01 August, nearly two thirds of these during July (Table 1). Larger bull trout tended to appear in the trap earlier than smaller bull trout, which has occurred all four years we have trapped bull trout in Mill Creek (Fig. 3). 
Table 1. Lengths of Mill Creek bull trout captured in the upstream migrant trap during 2001.

\begin{tabular}{ccccc}
\hline & & \multicolumn{3}{c}{ FL (mm) } \\
\cline { 3 - 5 } Month & N & Min & Max & $\bar{x}$ \\
\hline Jun & 29 & 330 & 710 & 512 \\
Jul & 69 & 287 & 697 & 447 \\
Aug & 38 & 239 & 584 & 385 \\
Sep & 19 & 326 & 617 & 398 \\
Oct & 1 & -- & -- & 212 \\
\hline
\end{tabular}

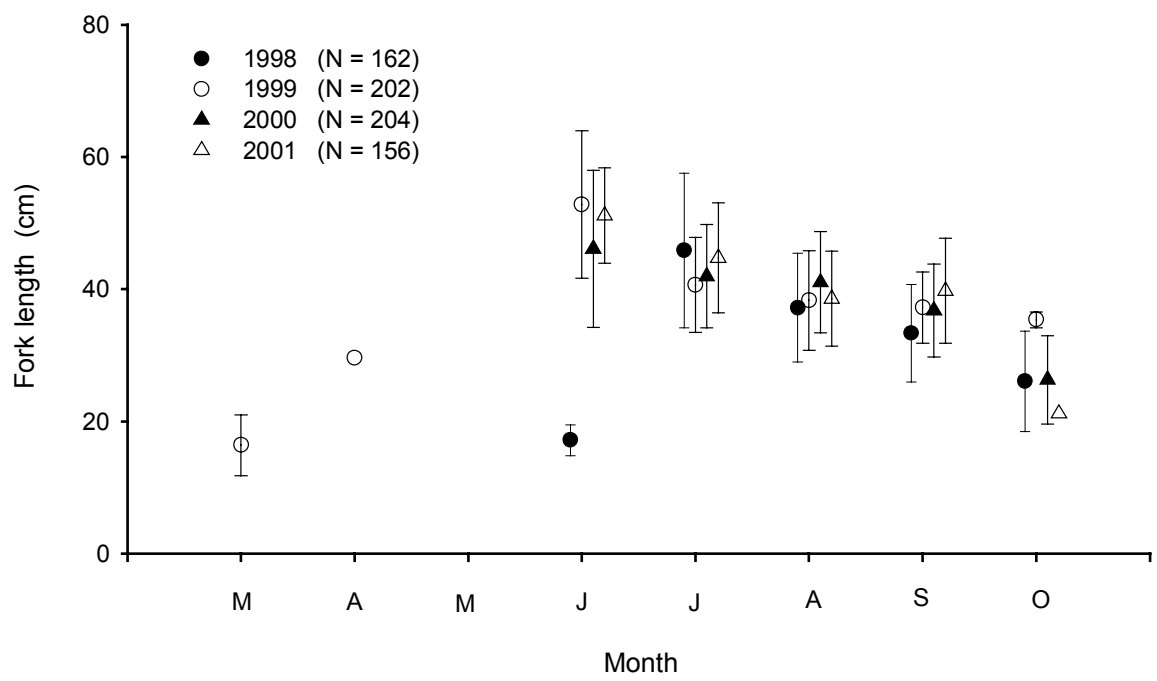

Figure 3. Monthly mean fork lengths $( \pm S D)$ of Mill Creek bull trout captured in the upstream migrant trap during four years.

We installed the rotary screw trap in Mill Creek on 04 September 2001 and operated it continuously through 25 March 2002, except for three consecutive days late in February. This trap was checked daily all but 10 days of operation. It captured 215 bull trout, 212 of which were measured with lengths ranging from 36 to $607 \mathrm{~mm}$, with a mean of $187 \mathrm{~mm}$ (Fig. 4). These length statistics are similar to those of bull trout captured by screw trap during March through October 2000 (range $=34-611 \mathrm{~mm}$, mean = $162 \mathrm{~mm}$; Hemmingsen, Gunckel, Sankovich and Howell 2001). 

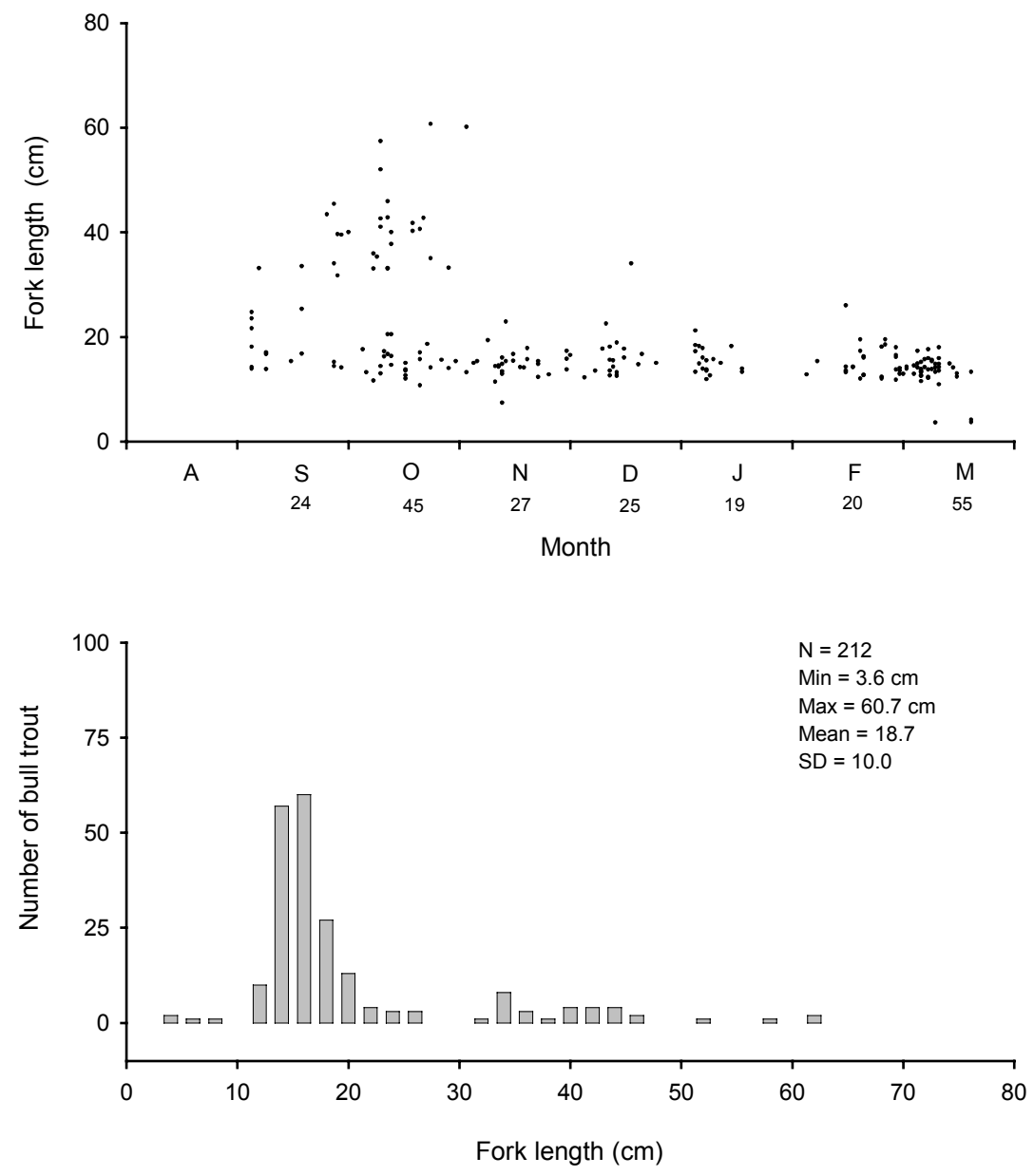

Figure 4. Numbers and lengths of bull trout in Mill Creek captured in the screw trap in 2001. Monthly totals are shown under corresponding months.

Eighty-five percent $(n=181)$ of the bull trout captured by the screw trap from September 2001 through March 2002 were less than $300 \mathrm{~mm} ; 29 \%$ of these $(n=53)$ were captured in March. The length distributions of these bull trout were similar each month (Table 2). We have captured bull trout of similar lengths during March through October of 1998-2000 (Hemmingsen, Gunckel, Sankovich and Howell 2001). Together, these data indicate emigration of juvenile bull trout yearround in Mill Creek, and that this emigration occurs at a critical size range. Fifteen percent $(n=31)$ of the bull trout captured by the screw trap were $300 \mathrm{~mm}$ or larger. All but two were captured during September and October; none were captured after December.

In addition to bull trout, the screw trap captured 329 juvenile Oncorhynchus tshawytscha (4-78 $\mathrm{mm}), 45$ O. mykiss (25-360 mm), 5 Catostomus spp (160-230 mm), 7 Prosopium williamsoni (195$440 \mathrm{~mm})$, and 35 Cottus spp (60-110 mm) from September 2001 through March 2002. 
Table 2. Mill Creek bull trout captured in the screw trap during 2001-02.

\begin{tabular}{cccccc}
\hline & \multicolumn{5}{c}{ FL (mm) } \\
\cline { 3 - 6 } Month & N & \multicolumn{5}{c}{ Min } & Max & $\bar{x}$ & SD \\
\hline & \multicolumn{5}{c}{$<\mathbf{3 0 0}$ mm FL } \\
Sep & 15 & 138 & 253 & 176 & 41 \\
Oct & 24 & 107 & 205 & 152 & 26 \\
Nov & 26 & 74 & 229 & 148 & 27 \\
Dec & 24 & 122 & 225 & 156 & 25 \\
Jan & 19 & 119 & 212 & 155 & 24 \\
Feb & 20 & 120 & 260 & 151 & 34 \\
Mar & 53 & 36 & 195 & 138 & 31 \\
& & $\geq 300$ & mm FL & & \\
Sep & 12 & 304 & 330 & 375 & 52 \\
Oct & 21 & 302 & 607 & 411 & 76 \\
Nov & 1 & -- & -- & 601 & -- \\
Dec & 1 & -- & -- & 340 & - \\
Jan & 0 & -- & -- & -- & - \\
Feb & 0 & -- & -- & -- & -- \\
Mar & 0 & -- & -- & -- & -- \\
\hline
\end{tabular}

The efficiency at which the Mill Creek rotary screw trap captured bull trout of all sizes during September 2001 through March 2002 averaged 35\%, although there was considerable monthly variation (Table 3). The overall average, however, is similar to the estimated overall average of $38 \%$ in 2000 (Hemmingsen, Gunckel, Sankovich and Howell 2001). Using bootstrap methods, we estimated that between 463 and 741 bull trout $(602 \pm 139)$ passed downstream at this location. It should be noted that the estimated number of bull trout assumes that these fish pass the trap only once. Based on evidence from PIT tags however, a small number of bull trout can be recaptured more than once and thereby cause over-estimation of the actual number that passed downstream. Calculation of the estimated number also assumes that all marked bull trout placed upstream move back downstream past the trap. Marked bull trout that do not move back downstream cause the total number to be under-estimated.

Table 3. Efficiencies at which the Mill Creek rotary screw trap captured bull trout, and the estimated numbers of them that passed downstream in 2001-2002.

\begin{tabular}{|c|c|c|c|c|c|c|c|c|}
\hline & Sep & Oct & Nov & Dec & Jan & Feb & Mar & Sep-Mar \\
\hline \multicolumn{9}{|l|}{ Trap } \\
\hline efficiency $(\%)^{a}$ & 5.6 & 18.5 & 46.2 & 30.8 & 47.4 & 20.0 & 53.1 & 35.1 \\
\hline \multicolumn{9}{|l|}{ Estimated } \\
\hline number of bull trout & 218 & 292 & 60 & 83 & 43 & 126 & 96 & 602 \\
\hline $\begin{array}{c}95 \% \text { confidence } \\
\text { interval }\end{array}$ & 383 & 366 & 33 & 69 & 30 & 167 & 32 & 139 \\
\hline
\end{tabular}


Of the 31 bull trout greater than $300 \mathrm{~mm}$ captured in the rotary screw trap, 14 had PIT tags (125 $\mathrm{KHz}$ ) applied in years prior to 2001. Because the PIT tag scanner used in the field read only 125 $\mathrm{KHz}$ tags, these 14 bull trout were used to estimate the time spent on a spawning migration upstream of the Mill Creek dam during 2001. This time period was defined as the elapsed days between captures in both traps. These 14 bull trout (range $=331-514 \mathrm{~mm}$, mean $=414 \mathrm{~mm}$ ) were captured in the upstream migrant trap at the ladder from 28 June to 13 August. An average of 65 days (range $=25-156$ days) had elapsed by the time they were recaptured in the screw trap. Generally, bull trout captured in the upstream migrant trap early in the run were recaptured in the screw trap later than bull trout that had been captured in the upstream trap relatively late in the run.

\section{$\underline{\text { Telemetry }}$}

We conducted 27 telemetry surveys in Mill Creek during January (5), February (4), March (4), April (4), May (5), June (4), and August (1) of 2001. These surveys were conducted by foot or by truck because surveys late in 2000 indicated all active transmitters were located between the water intake dam (Rkm 40.9) and the city of Walla Walla. On 04 January, the first survey of 2001, we located 10 transmitters that still produced signals. Six of these 10 transmitters remained at the locations where they were detected on the first survey. The remaining four transmitters were tracked downstream 0.5 - $20 \mathrm{~km}$ by 05 April to 15 May, where they remained until late June (Table 4). One additional transmitter was located three times at Rkm 38.6 during June. No telemetry surveys were conducted during July; no signals were detected when the final survey was conducted in August.

No transmitter located during 2001 moved upstream during spring and early summer, which we had frequently observed in previous years. All transmitters were located from three to 27 times at their final destinations, and no bull trout were observed at these destinations. Therefore, we concluded that for most of 2001, the transmitters had been rejected by the bull trout that originally carried them, or that these bull trout were dead. Of the 11 transmitters we located in Mill Creek during 2001, seven were implanted in bull trout during 1998 and four were implanted during 1999.

We conducted nine telemetry surveys in the Grande Ronde Basin during 2001. Three of these surveys were by plane, once during April and twice during July. Four surveys, limited to short portions of the Grande Ronde River, occurred by foot during January, March, May and June. Two surveys were by truck in February and November; the latter occurred on the Grande Ronde River from the bridge on highway 3 to Wildcat Creek. On these surveys, we tracked 12 bull trout captured from the Wenaha River or Lookingglass Creek and implanted with radio transmitters in 1998 or 1999 (Table 5).

Three of these 12 transmitters were located only once in 2001; these locations were in the Grande Ronde River (Rkm 38.6 and 42.2) and the Wenaha River (Rkm 31.2, between Rock Creek and NF Wenaha River). The remaining nine transmitters were each detected two to seven times between 22 February and 31 July. Of these nine transmitters, four remained where they were first detected, two in the Grande Ronde River at about Rkm 52 and two in the Wenaha River (Rkm 28.0 and 29.6). The remaining five of these nine transmitters moved somewhat during the time they were tracked. Three were located in the Grande Ronde River, and moved downstream 1 to $3 \mathrm{~km}$. Only two transmitters indicated any upstream movement in 2001. One (frequency 151.613) was located in the Grande Ronde River at Rkm 86.6 on 22 February. The bull trout carrying this transmitter moved downstream $12.6 \mathrm{~km}$ to the Wenaha River, then upstream to Rkm 36.8 of the Wenaha River by the 
end of July. The other (frequency 151.622) moved from the confluence of the Wenaha River upstream to Rkm 24.3 of the Wenaha River by the end of July.

No telemetry surveys were conducted during August through October because we thought few transmitters were in live fish (this includes rejected tags). No signals were detected when a final survey was conducted in November.

Table 4. Radio-tagged bull trout of Mill Creek that were tracked in 2001.

\begin{tabular}{|c|c|c|c|c|c|c|}
\hline MHz & $L(m m)^{a}$ & LU & TU & LD & TD & $\begin{array}{l}\text { Last } \\
\text { Found }\end{array}$ \\
\hline \multicolumn{7}{|c|}{ Tagged in 1998: } \\
\hline 150.073 & 605 & $37.4^{b}$ & 04 Jan & -- & -- & 27 Jun \\
\hline 150.105 & 535 & $29.8^{b}$ & 04 Jan & -- & -- & 15 May \\
\hline 150.123 & 520 & $24.8^{b}$ & 04 Jan & -- & -- & 27 Jun \\
\hline 150.134 & 545 & 40.6 & 04 Jan & 20.5 & $11 \mathrm{Apr}$ & 27 Jun \\
\hline 150.192 & 630 & 19.2 & 04 Jan & 18.6 & 15 May & 27 Jun \\
\hline 150.343 & 510 & $38.6^{b}$ & 14 Jun & -- & -- & 27 Jun \\
\hline 150.713 & 555 & 20.3 & 04 Jan & 18.7 & 15 May & 27 Jun \\
\hline \multicolumn{7}{|c|}{ Tagged in 1999: } \\
\hline 151.273 & 360 & $38.9^{b}$ & 04 Jan & -- & -- & 08 May \\
\hline 151.312 & 315 & $40.6^{b}$ & 04 Jan & -- & -- & 27 Jun \\
\hline 151.343 & 358 & $37.0^{\mathrm{b}}$ & 04 Jan & -- & -- & 27 Jun \\
\hline 151.681 & 395 & 40.6 & 04 Jan & 35.4 & $05 \mathrm{Apr}$ & $05 \mathrm{Apr}$ \\
\hline
\end{tabular}


Table 5. Radio-tagged bull trout of the Grande Ronde basin that were tracked in 2001. Unless otherwise noted, all were captured and tagged from the Wenaha River. Locations shown are in the Grande Ronde River, unless otherwise noted.

\begin{tabular}{|c|c|c|c|c|c|c|}
\hline MHz & $L(\mathrm{~mm})^{a}$ & LU & TU & LD & TD & $\begin{array}{l}\text { Last } \\
\text { Found }\end{array}$ \\
\hline \multicolumn{7}{|c|}{ Tagged in 1998: } \\
\hline 150.053 & 530 & 38.6 & $02 \mathrm{Jul}$ & -- & -- & $02 \mathrm{Jul}^{\mathrm{b}}$ \\
\hline 150.114 & 520 & $31.2^{c}$ & $31 \mathrm{Jul}$ & -- & -- & $31 \mathrm{Jul}^{\mathrm{b}}$ \\
\hline 150.115 & 535 & $29.6^{c d}$ & $27 \mathrm{Apr}$ & -- & -- & $02 \mathrm{Jul}$ \\
\hline 150.133 & 630 & 42.2 & $22 \mathrm{Feb}$ & 39.8 & $27 \mathrm{Apr}$ & $02 \mathrm{Jul}$ \\
\hline 150.343 & 483 & $51.8^{d}$ & $22 \mathrm{Feb}$ & -- & -- & $02 \mathrm{Jul}$ \\
\hline 150.743 & 565 & 61.6 & $22 \mathrm{Feb}$ & 58.4 & $02 \mathrm{Jul}$ & $31 \mathrm{Jul}$ \\
\hline 151.223 & 546 & $28.0^{c d}$ & $02 \mathrm{Jul}$ & -- & -- & $31 \mathrm{Jul}$ \\
\hline 151.262 & $444^{e}$ & 85.6 & 04 Jan & 84.5 & $31 \mathrm{Jul}$ & $31 \mathrm{Jul}$ \\
\hline \multicolumn{7}{|c|}{ Tagged in 1999: } \\
\hline 150.032 & 340 & $52.0^{d}$ & $22 \mathrm{Feb}$ & -- & -- & 02 July \\
\hline 151.092 & 375 & 42.2 & $22 \mathrm{Feb}$ & -- & -- & $22 \mathrm{Feb}^{\mathrm{b}}$ \\
\hline 151.613 & 350 & $36.8^{c}$ & $31 \mathrm{Jul}$ & 86.6 & $22 \mathrm{Feb}$ & $31 \mathrm{Jul}$ \\
\hline 151.622 & 330 & $24.3^{c}$ & $31 \mathrm{Jul}$ & 73.9 & $27 \mathrm{Apr}$ & $31 \mathrm{Jul}$ \\
\hline
\end{tabular}

$\mathrm{LU}=$ maximum known upstream location (Rkm) in 2001.

$\mathrm{TU}=$ earliest date of maximum upstream location.

$\mathrm{LD}=$ maximum downstream location (Rkm) 2001.

TD = earliest date of maximum downstream location.

a Length when implanted with radio transmitters.

${ }^{\mathrm{b}}$ Located once in 2001.

${ }^{\mathrm{c}}$ Located in the Wenaha River.

d Always located here.

e Tagged in Lookingglass Creek. 


\section{Stream temperature monitoring}

\section{Introduction}

Bull trout are stenothermic, requiring cold water temperatures to rear and reproduce. Consequently, the distribution of bull trout may be determined, in part, by the stream temperature regime. Elevated water temperature is considered to be a significant factor in the decline of bull trout in Oregon and the Pacific Northwest (Buchanan and Gregory 1997). Although bull trout have been observed in water $>20^{\circ} \mathrm{C}$, temperatures $>16^{\circ} \mathrm{C}$ are considered unsuitable for long-term survival (Selong et al. 2001). Rieman and Chandler (1999) showed that bull trout of the Pacific Northwest were most likely to be found in streams where the summer maximum temperatures were $<14^{\circ} \mathrm{C}$. Gamett (2002) found bull trout were present at locations where the mean temperature between July 1 and Sept 30 was $<10^{\circ} \mathrm{C}$, and were not found where mean temperature was $>12^{\circ} \mathrm{C}$. In laboratory conditions, the fundamental thermal niche of juvenile bull trout was $10.2-14.2^{\circ} \mathrm{C}$ (Selong et al. 2001).

Our objective is to describe the relationship between stream temperature and distribution of bull trout in Oregon's portion of the Columbia River Basin. This section describes efforts to measure the thermal characteristics of streams where we are monitoring bull trout movements, including Mill Creek (Walla Walla Basin), the upper John Day River watershed, and the Grande Ronde Basin.

\section{Methods}

Thirty-four temperature data loggers (Onset Computer, Inc.) were deployed in the study basins: 9 in Mill Creek, 16 in the John Day River, and 9 in Grande Ronde watersheds (Table 6). Temperature data loggers were launched between December 2000 and July 2001. Data loggers were collected and downloaded from September through November 2001.

Temperature data loggers were programmed with a recording interval of one hour. In small streams and rivers at low flows, data loggers were placed in a sock or mesh bag with a few heavy stones. The bag was placed on the substrate at the edge of the thalweg to ensure its location in an area of adequate mixing. In large rivers or at high winter or spring flows, data loggers were placed in a perforated metal pipe with a screw cap and an eyebolt on one end. The pipe was secured with cable to a stable structure (e.g., a tree) on the stream bank. 
Table 6. Location and duration of temperature data loggers deployed in 2001.

\begin{tabular}{|c|c|c|c|c|c|c|}
\hline Basin & Stream & $\begin{array}{l}\text { Launch } \\
\text { Date }\end{array}$ & $\begin{array}{c}\text { Re- } \\
\text { launch } \\
\text { Date }^{a}\end{array}$ & $\begin{array}{c}\text { Recovery } \\
\text { Date }^{a}\end{array}$ & $\begin{array}{c}\text { River } \\
\text { Kilometer }\end{array}$ & Location Description \\
\hline \multirow[t]{5}{*}{ Mill Creek } & Mill Cr. & 12-Dec-00 & 4-Jun & 23-Oct & 5 & Wallula bridge \\
\hline & $"$ & 12-Dec-00 & 4-Jun & 18-Oct & 21 & 5 mile bridge \\
\hline & $"$ & 12-Dec-00 & 4-Jun & 12-Sep & 31 & Wickersham bridge \\
\hline & $"$ & 12-Dec-00 & 4-Jun & 23-Oct & 43 & screw trap site \\
\hline & $"$ & 10-Jul-01 & & $18-O c t$ & 49 & confluence with North Fork \\
\hline \multirow[t]{13}{*}{ John Day } & $\begin{array}{l}\text { NF John Day } \\
\text { R. }\end{array}$ & 12-Dec-00 & & * & 4 & 2 miles above Kimberly \\
\hline & John Day R. & 12-Dec-00* & 16-Mar & * & 270 & Spray boat launch \\
\hline & $"$ & 12-Dec-00 & & * & 414 & highway 26 bridge \\
\hline & “ & 30-Mar-01* & 21-Jun & 15-Nov & 435 & at 1999 screw trap site \\
\hline & $"$ & 12-Dec-00 & & * & 437 & at Reynolds Cr. road x-ing \\
\hline & $"$ & 12-Dec-00 & & 15-Nov & 444 & road 62 bridge \\
\hline & $"$ & $6-\mathrm{Dec}-00^{*}$ & 21-Jun & * & 455 & end of fish use \\
\hline & Indian Cr. & 1-Jun-01 & & 06-Oct & 10 & confluence with Sheep Cr. \\
\hline & Dixie $\mathrm{Cr}$. & 5-Dec-00 & & 15-Nov & 14 & 2/3 way up Dixie Cr. \\
\hline & Reynolds Cr. & 12-Dec-00 & & 15-Nov & 4 & USFS boundary \\
\hline & $"$ & 12-Dec-00 & & 15-Nov & 7 & USFS campground \\
\hline & Call Cr. & 6-Dec-00 & & 15-Nov & 0.1 & \\
\hline & $"$ & 6-Dec-00 & & * & 3 & \\
\hline \multirow[t]{4}{*}{$\begin{array}{l}\text { Grande } \\
\text { Ronde }\end{array}$} & $\begin{array}{l}\text { Grande Ronde } \\
\text { R. }\end{array}$ & 29-Nov-00 & 7-Jul & 27-Nov & 44 & $\begin{array}{l}1.6 \mathrm{Km} \text { above of Hwy } 3 \\
\text { bridge }\end{array}$ \\
\hline & $"$ & 8-Dec-00* & 7-Jul & 27-Nov & 85 & $1.2 \mathrm{~km}$ below of Wildcat $\mathrm{Cr}$. \\
\hline & $"$ & 15-Aug-01 & & $15-$ Oct & 127 & 300 m below Rondowa \\
\hline & $"$ & 25-Nov-00 & 7-Jul & 29-Nov & 132 & $1 \mathrm{~km}$ below Lookingglas $\mathrm{Cr}$. \\
\hline Wenaha & Wenaha R. & 10-Mar-01 & 7-Jul & 27-Nov & 0.8 & $800 \mathrm{~m}$ upstream from mouth \\
\hline
\end{tabular}

* Data logger malfunctioned or was lost.

a 2001. 


\section{Results and Discussion}

\section{Mill Creek}

Nine temperature data loggers were deployed at five sites in Mill Creek (Fig. 5). Sites were monitored at various times between 12 December 2000 and 23 October 2001 (Table 6). The seven hottest consecutive days in 2001 occurred between $8-14$ July. For these days the average maximum stream temperature above Rkm 32 did not exceed $20^{\circ} \mathrm{C}$ (Fig 6a). Temperatures at Rkm 32 were above $15^{\circ} \mathrm{C}$ for an average of $12 \mathrm{hrs}$ per day and sites upstream did not exceed $15^{\circ} \mathrm{C}$ (Fig $6 b)$. Temperatures at RKm 43 did not exceed $13^{\circ} \mathrm{C}$ during the week.

The temperature data logger at Rkm 49 did not capture this time period; however, temperatures were typically $1.5^{\circ} \mathrm{C}$ (range $=0.8-2.3^{\circ} \mathrm{C}$ ) cooler than at Rkm 43 in late July and September. At $\mathrm{Rkm} 43$ and Rkm 49 the mean temperature 10 July -30 September was $<10^{\circ} \mathrm{C}$. The average daily fluctuation during July and August was greatest, $7^{\circ} \mathrm{C}$ (range $=2.5-9.1^{\circ} \mathrm{C}$ ), at Rkm 32 (Fig 6c). Temperatures at $\mathrm{Rkm} 49$ were the most stable, varying by $1.9^{\circ} \mathrm{C}$ (range $=0.6-2.6^{\circ} \mathrm{C}$ ). The greatest temperature fluctuation $\left(9.5^{\circ} \mathrm{C}\right)$ occurred at Rkm 21 on 22 May 2001.

In winter, the 7-day average minimum temperatures at all sites remained at or below $5^{\circ} \mathrm{C}$ through 15 February. The 7-day average minimum temperature at Rkm 21 was consistently cooler than other sites and fluctuated between $1.7^{\circ} \mathrm{C}$ and $3.7^{\circ} \mathrm{C}$ from 19 December 2000 to 7 March 2000. Rkm 5 was the warmest, fluctuating between $3.4-7.1^{\circ} \mathrm{C}$ during the same period. Temperatures slowly began to increase in mid-March except at Rkm 5 which started to warm in mid-February.

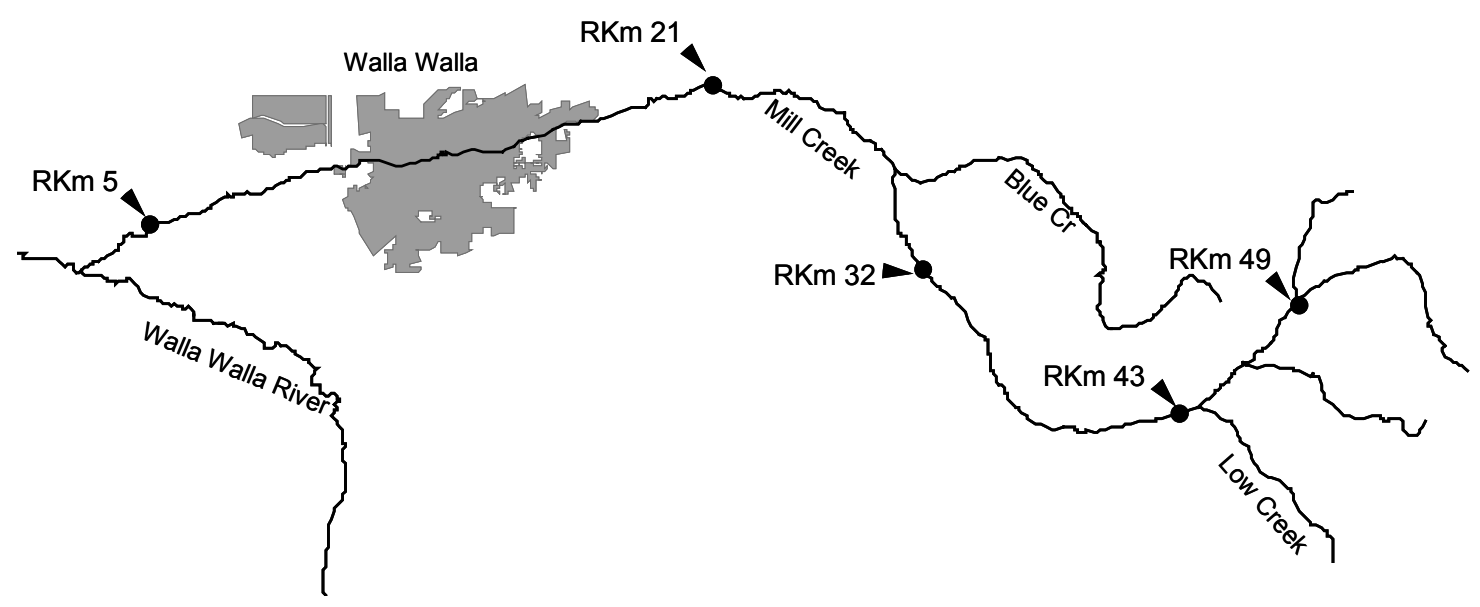

Figure 5. Locations of temperature data loggers in Mill Creek during 2001. 

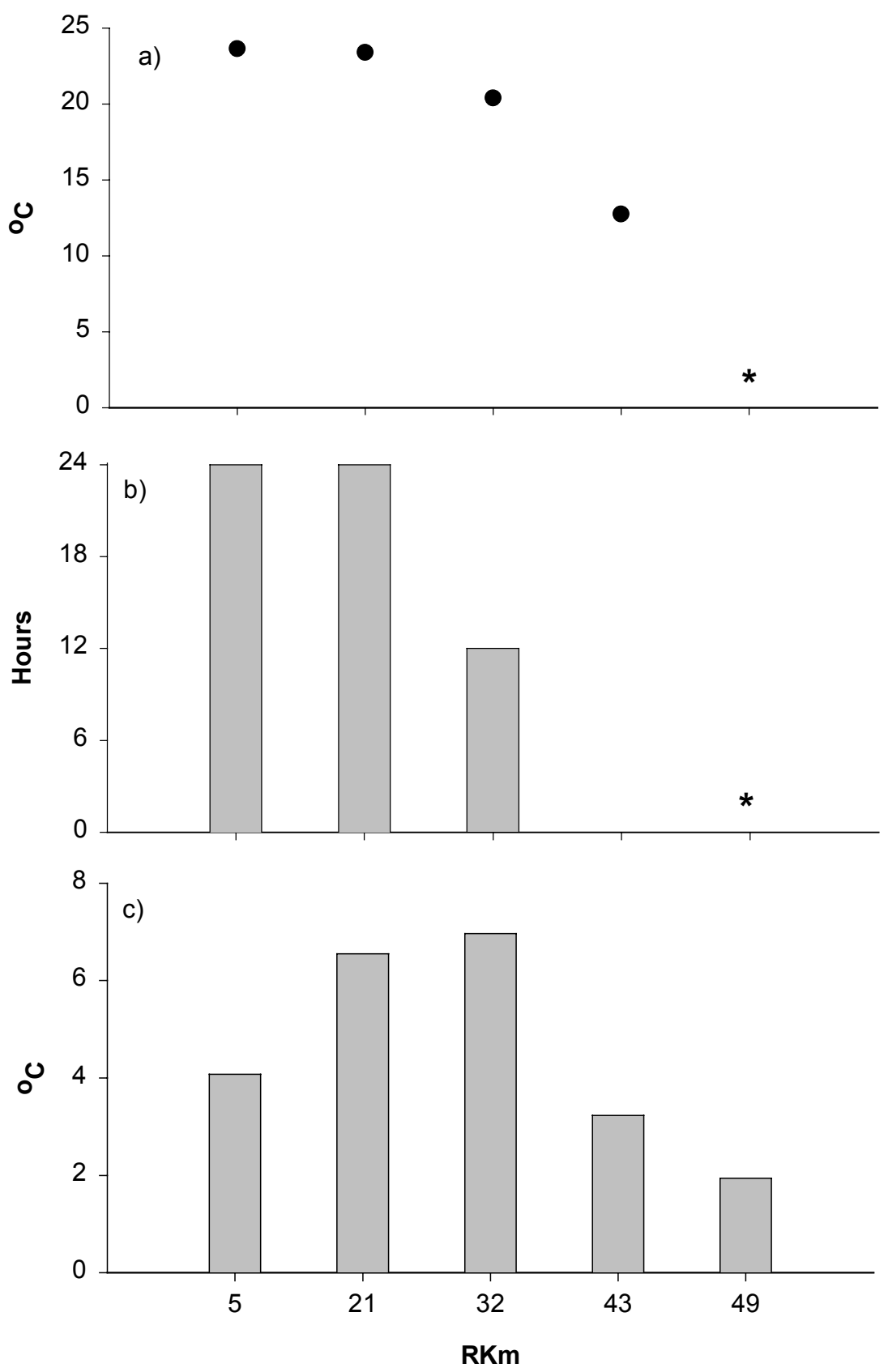

Figure 6. Seven day average a) maximum temperature and b) number of hours $>15^{\circ} \mathrm{C}$ during 8 14 July 2001 in Mill Creek. c) Average degrees of fluctuation during July and August 2001. * The temperature data logger at Rkm 49 was not deployed during this time period. 


\section{John Day River}

Thirteen temperature data loggers were deployed at 11 sites in both the upper mainstem and tributary streams (Fig. 7). Sites were monitored at various times between 5 December 2000 and 15 November 2001 (Table 6). Six temperature data loggers were lost or malfunctioned. Of these data loggers five were in the mainstem John Day (Rkm 414, Rkm 435 (1 of 2), Rkm 437, Rkm 455 (2) and one was in upper Call Creek. Three temperature data loggers were deployed in the lower John Day, two near Spray and one in the North Fork John Day River near Kimberly. All three data loggers were lost.

The seven hottest consecutive days occurred between 30 June and 6 July. For these days average maximum temperature did not exceed $20^{\circ} \mathrm{C}$ at any of the sites (Fig. 8a). The Call Creek site was the coolest where the maximum temperature averaged $11.4^{\circ} \mathrm{C}$. Call Creek and upper Reynolds Creek did not reach $15^{\circ} \mathrm{C}$, whereas RKm 435 and Dixie Creek exceed $15^{\circ} \mathrm{C}$ for 11 and 14 hours/day respectively (Fig. $8 \mathrm{~b}$ ). The mean temperature 1 July -30 September was $<10^{\circ} \mathrm{C}$ at Call Creek and Reynolds- 2 and $<12^{\circ} \mathrm{C}$ at all sites except Rkm 435.

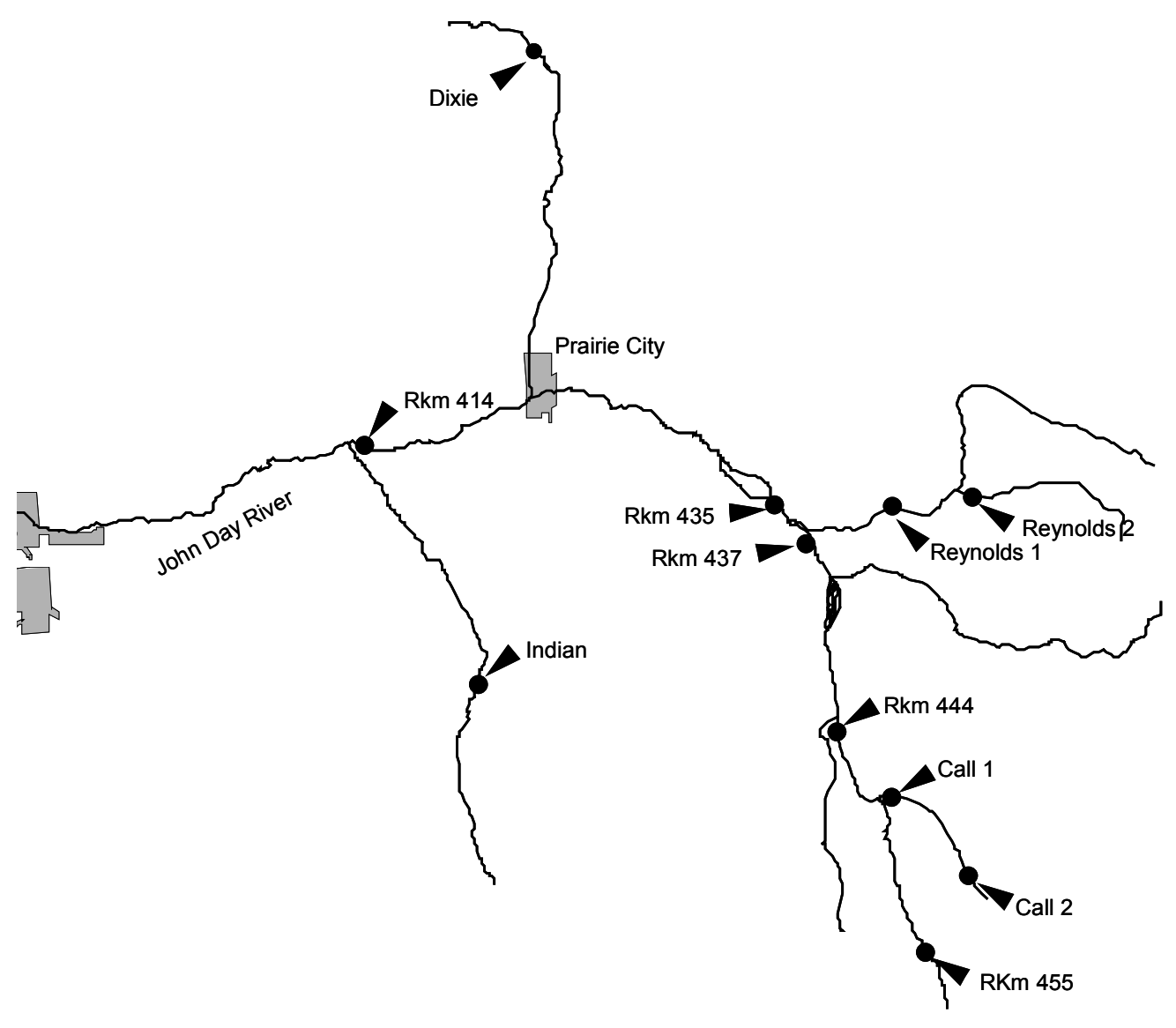

Figure 7. Location of temperature data loggers in the upper John Day Basin during 2001. 

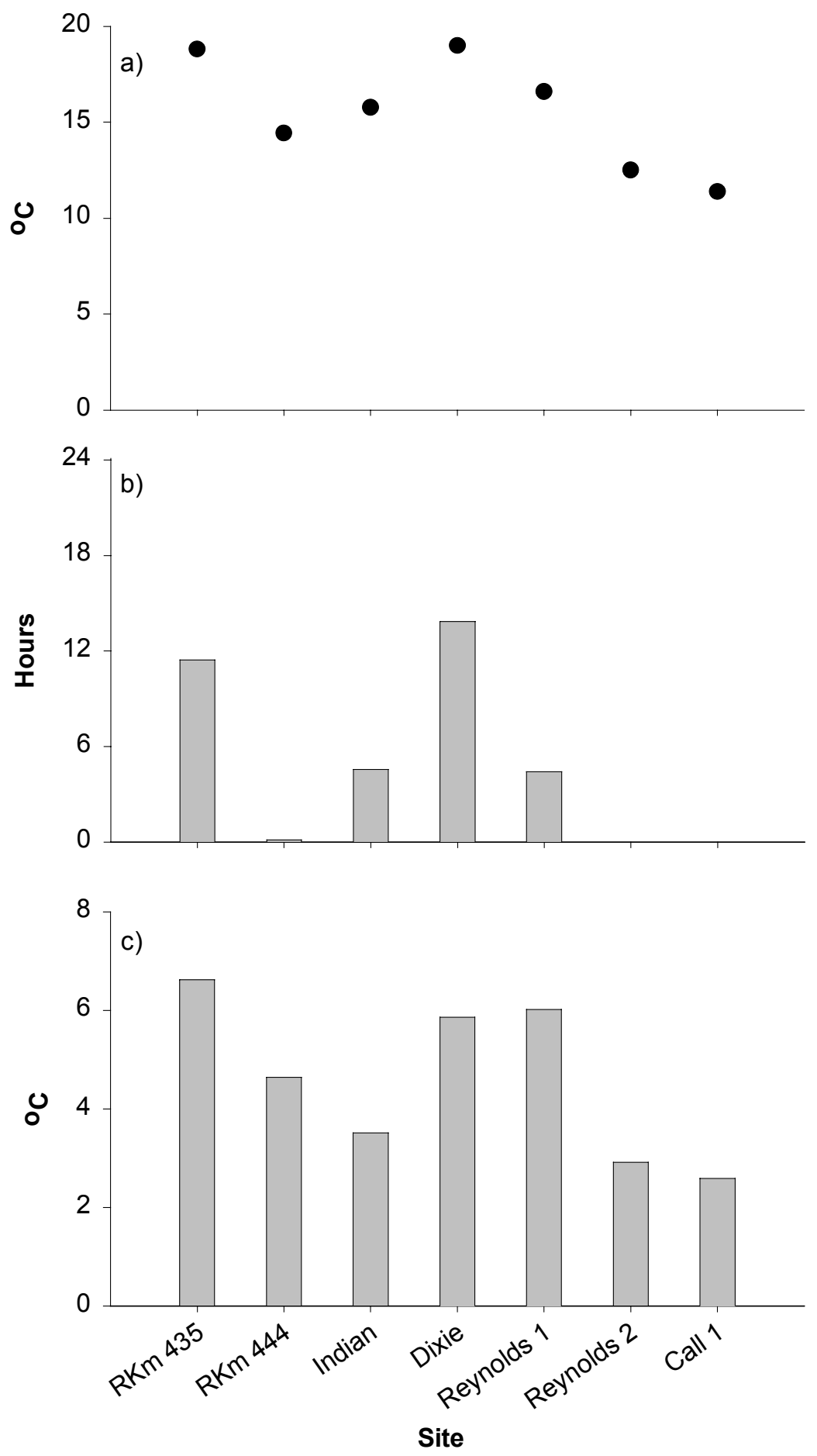

Figure 8. Seven day average a) maximum temperature and b) number of hours $>15^{\circ} \mathrm{C}$ during 30 June - 6 July 2001 in the John Day Basin. c) Average degrees of fluctuation during July and August 2001. 
Daily temperature fluctuation in July and August was greatest at the Rkm 435, which varied an average of $6.6^{\circ} \mathrm{C}$ daily (range $=2.5-8.5^{\circ} \mathrm{C}$ ). Call creek was the most stable with daily fluctuations averaging $2.5^{\circ} \mathrm{C}$ (range $\left.=0.8-3.8^{\circ} \mathrm{C}\right)($ Fig. $8 \mathrm{C})$. The greatest temperature fluctuation $\left(8.5^{\circ} \mathrm{C}\right)$ occurred at Rkm 435 on 8 August 2001.

In winter, all sites remained above $0^{\circ} \mathrm{C}$ except Dixie Creek. The 7-day average minimum temperature at Dixie Creek was at or below $1^{\circ} \mathrm{C}$ from 14 December 2000 to 16 April 2001. Reynolds- 1 was the warmest with 7-day minimum temperatures fluctuating between $3.9^{\circ} \mathrm{C}$ and $1.7^{\circ} \mathrm{C}$ between 20 December and 21 March. Water temperatures began increasing in mid-April.

\section{Grande Ronde River}

Nine temperature data loggers were located at five sites in the Grande Ronde Basin. Sites were monitored at various times between 25 November 2000 and 29 November 2001 (Fig. 9). Rkm 130 was monitored for 3 months between 16 August and 15 October. The data logger launched at Rkm 85 on 8 December 2000 was lost and replaced on 7 July.

The seven hottest consecutive days in 2001 occurred between 6 to 12 August for all sites except $\mathrm{Rkm}$ 132. For these days all temperature loggers except Rkm 132 exceeded $20^{\circ} \mathrm{C}$ and were warmer than $15^{\circ} \mathrm{C}$ for 24 hours per day (Fig. 10a \& b). The hottest consecutive seven days at Rkm 132 was 29 June to 5 July. During this week average maximum temperatures were $23.5^{\circ} \mathrm{C}$ and temperatures were $>15^{\circ} \mathrm{C}$ for 24 hours per day. The mean temperature from 1 July to 30 September was $>12^{\circ} \mathrm{C}$ at all sites.

The average daily temperature fluctuation during July and August was greatest at Rkm 132, which varied an average of $8.6^{\circ} \mathrm{C}$ daily (range $=2.6-10.9^{\circ} \mathrm{C}$ ). $\mathrm{Rkm} 44$ was the most stable with average daily fluctuations of $4.0^{\circ} \mathrm{C}$ (range $=9.9-5.6^{\circ} \mathrm{C}$ ). Stream temperature at the mouth of the Wenaha River during July and August was cooler than at Rkm 85 by an average of $4.7^{\circ} \mathrm{C}$. The degree of fluctuation was similar at these two sites.

Only two sites in the Grand Ronde basin were monitored during winter, Rkm 44 and Rkm 132. The 7-day average minimum temperature remained below $2.1^{\circ} \mathrm{C}$ until mid-February, when water temperature began to steadily rise. 


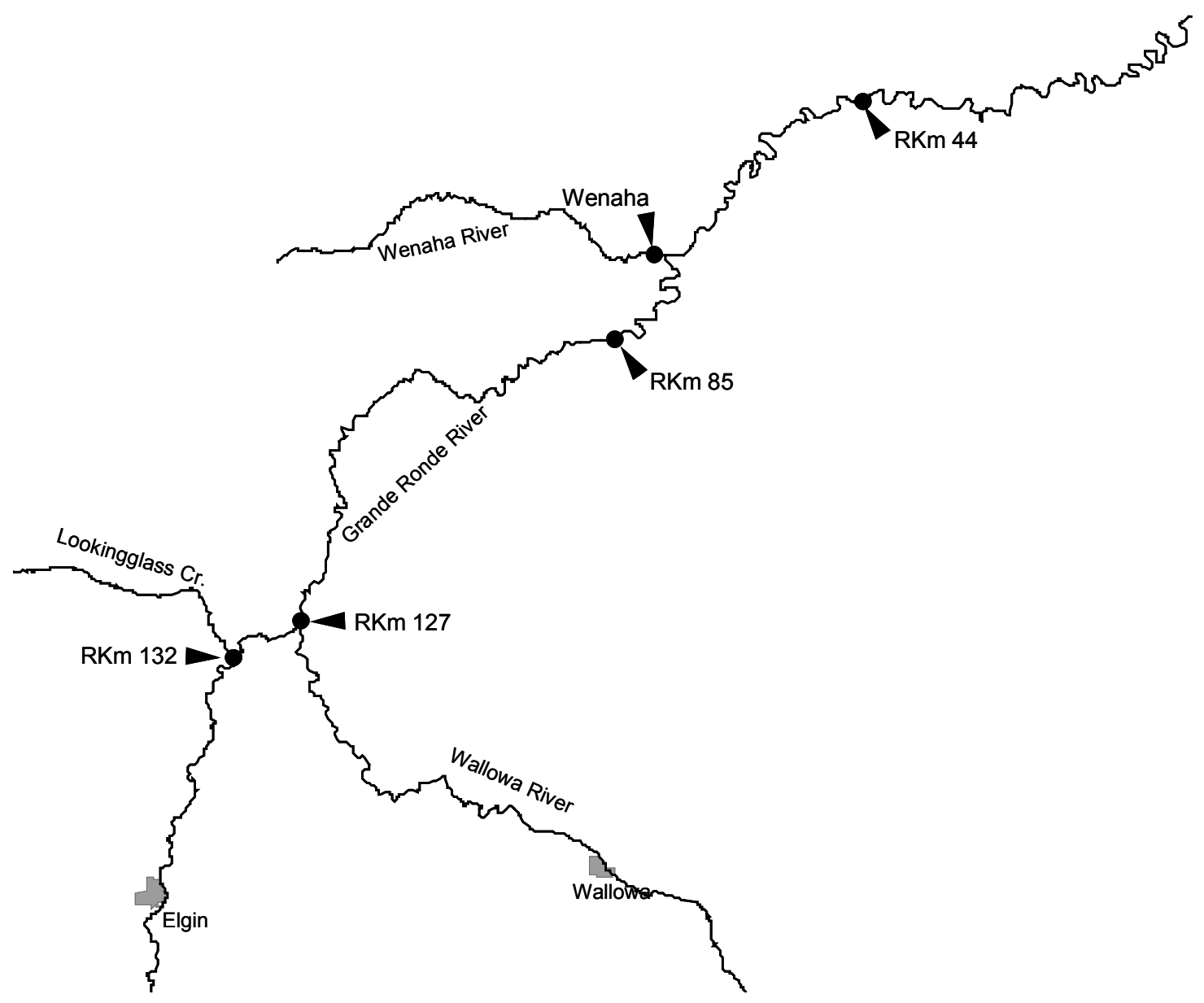

Figure 9. Location of temperature data loggers in the Grande Ronde Basin, during 2001. 

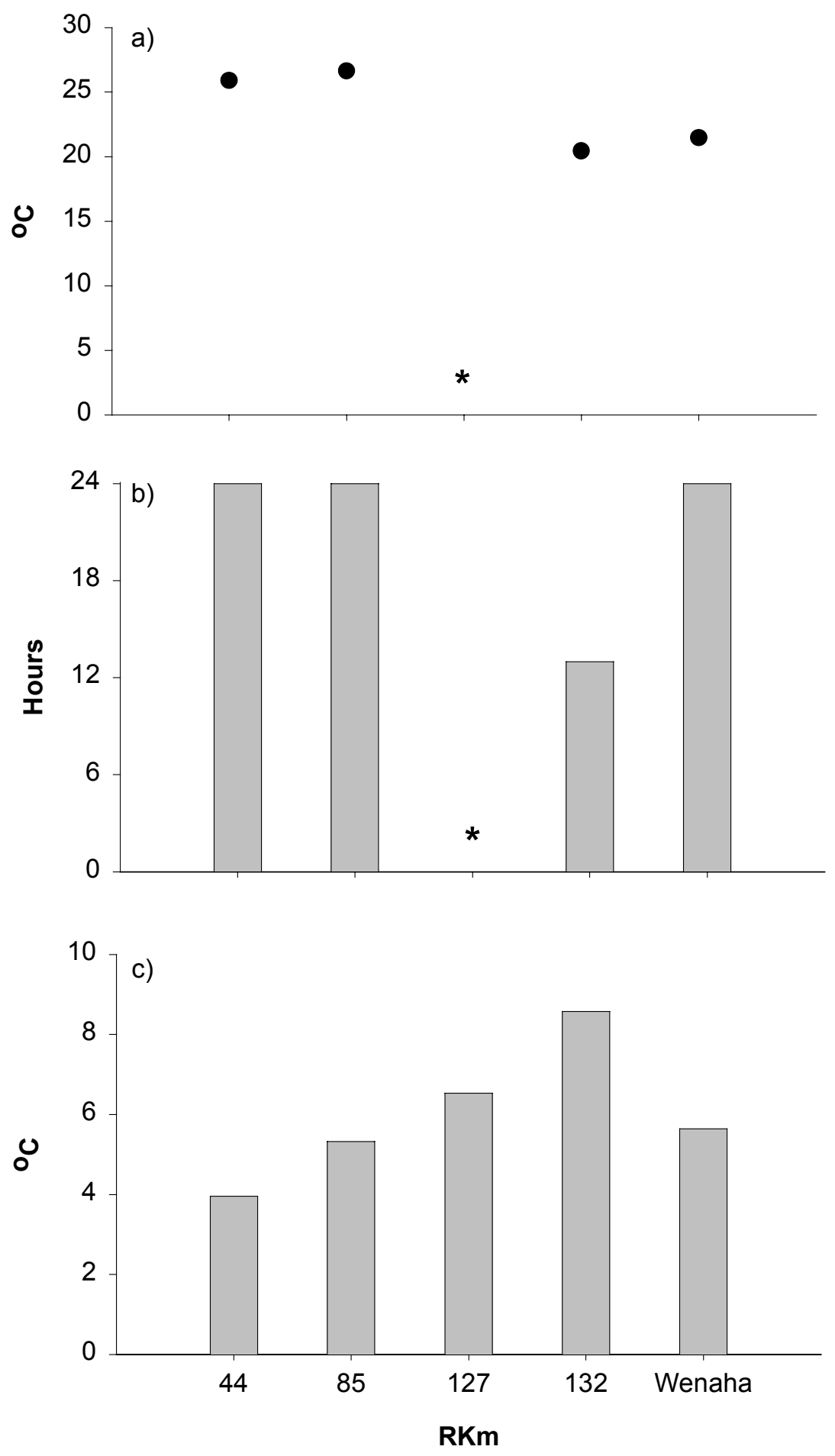

Figure 10. Seven day average a) maximum temperature and b) number of hours $>15^{\circ} \mathrm{C}$ during 6 12 August 2001 in the Grande Ronde Basin. c) Average degrees of fluctuation during July and August 2001. * The temperature data logger at Rkm 127 was not deployed during this time period. 


\section{Bull trout spawning surveys}

\section{Introduction}

Quantitative estimates of bull trout abundance are necessary to determine the status of populations, to monitor changes in population size, and to evaluate the effectiveness of conservation and recovery strategies. This information has been identified as critically needed research (Rieman and McIntyre 1993; Buchanan et al. 1997). Population status may be monitored at any or all life stages. However, it has been difficult for biologists to accurately quantify the abundance of emergent salmonid fry (Hillman et al. 1992) or find consistent measures of juvenile bull trout abundance (Bonneau et al. 1995; Thurow and Schill 1996).

Counting redds is an attractive technique to evaluate population abundance for several reasons. First, since only reproductive adults produce redds, the number of redds should reflect the effective population size of a stock (Meffe and Carroll 1994). However, this assumes that each female makes only one redd. Second, the potential impacts to the population from spawning ground surveys are relatively low when compared to potential injuries that can occur when making population estimates based on multiple-pass removal or mark-recapture techniques using electrofishing (see Hemmingsen et al. 1996). Third, counts of redds can be determined with relative ease.

Consequently, numbers of redds are commonly used to evaluate trends in the size of local bull trout populations (Rieman and Myers 1997). Despite their frequent use, the redd count information from spawning surveys may not be sufficient or appropriate to quantify the population status of bull trout. Detection of changes in population size may not be possible using the most extensive sets of redd count data available (7-17 years), (Maxell 1999) and is unlikely for populations with more limited data sets (Rieman and Myers 1997).

This section describes results of bull trout spawning surveys in Mill Creek (Walla Walla basin) and the Little Minam River (Grande Ronde basin). Areas where these surveys occur are relatively pristine and support two life history forms. Mill Creek supports fluvial bull trout while its tributaries are suspected to support resident bull trout. The reaches of the Little Minam River that we surveyed support only resident bull trout. These surveys provide additional data to complement those which began to be collected in 1996 so that we can better describe the population status of bull trout in these watersheds and better understand the spatial variation of redd distribution within each basin.

\section{Methods}

We conducted four spawning surveys in Mill Creek and its tributaries from the city of Walla Walla's water intake dam at river kilometer 40.9 (Fig. 11). Two surveys occurred in September (6-7 and 2021) and two occurred in October (4-5 and 18-19). Tributaries Burnt Fork and Bull creeks were not surveyed during the early October survey, and Deadman Creek was surveyed only during the late September survey. We also conducted four spawning surveys in the Little Minam River (upstream from Boulder Creek) and in its tributary Dobbin Creek (Fig. 12). Two surveys occurred in September (13-14 and 27-28) and two occurred in October (11-12 and 26-27). Survey reach numbers shown in Fig. 11 and Fig. 12 coincide with survey reach boundaries and lengths described by Hemmingsen, Bellerud, Buchanan, Gunckel, Shappart and Howell (2001). Surveys in each watershed were conducted with protocols consistent with surveys conducted from 1996 through 2000 (Hemmingsen, Gunckel, Sankovich and Howell 2001).

We determined the variation in distribution of bull trout redds within both the Mill Creek and Little Minam River watersheds using data collected during six years of surveys. This variation was 
expressed as the annual percentage of redd abundance that occurred in each stream reach. We expanded annual counts from reaches with low variation by respective six-year mean proportions to obtain annual estimated redd totals $(y)$ within each watershed. We compared $y$ with the annual observed redd totals $(x)$ and determined the percentage error between the two values by the calculation $((y-x) / x)^{*} 100$. 


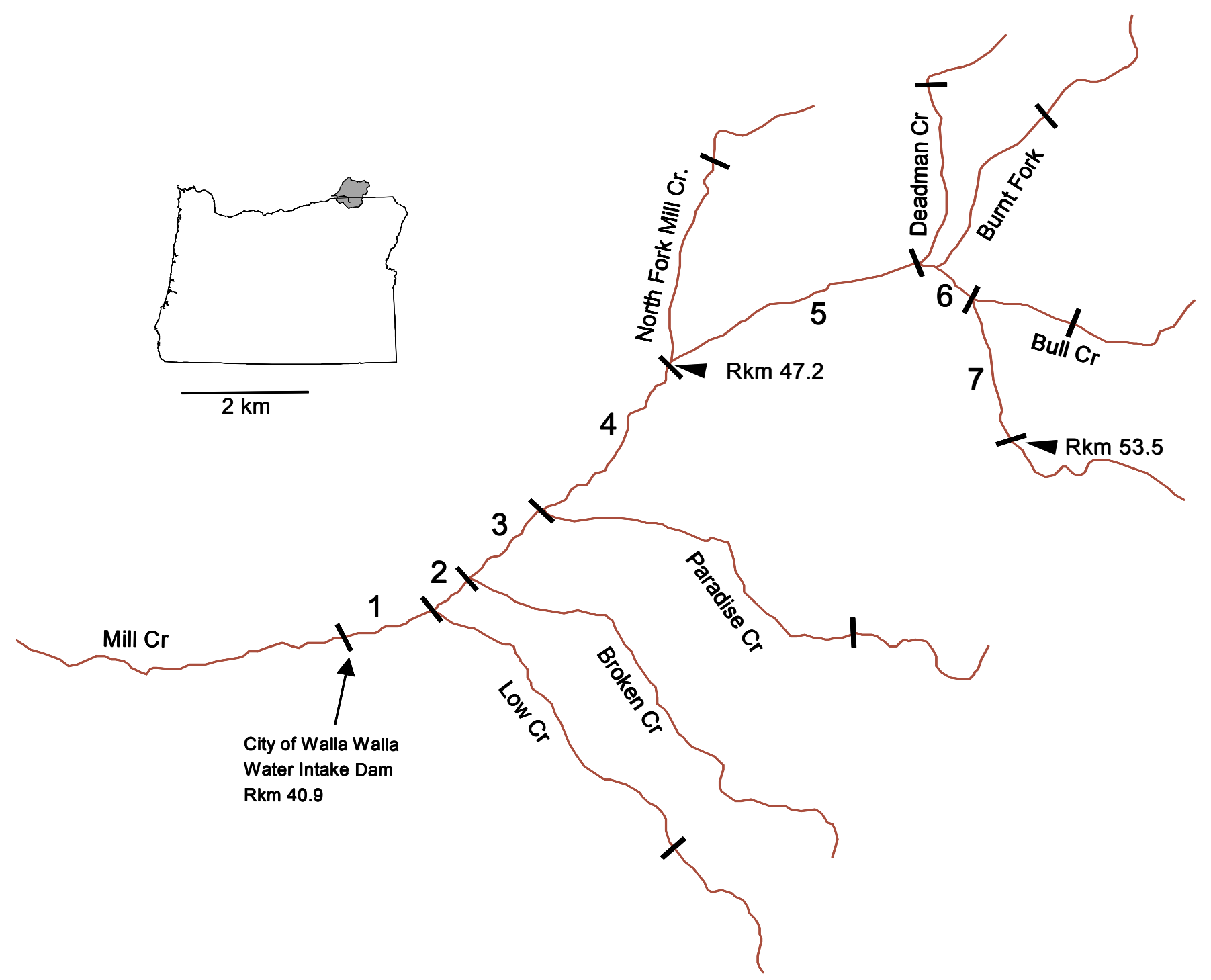

Figure 11. Locations of bull trout spawning survey reaches in Mill Creek and tributaries. 


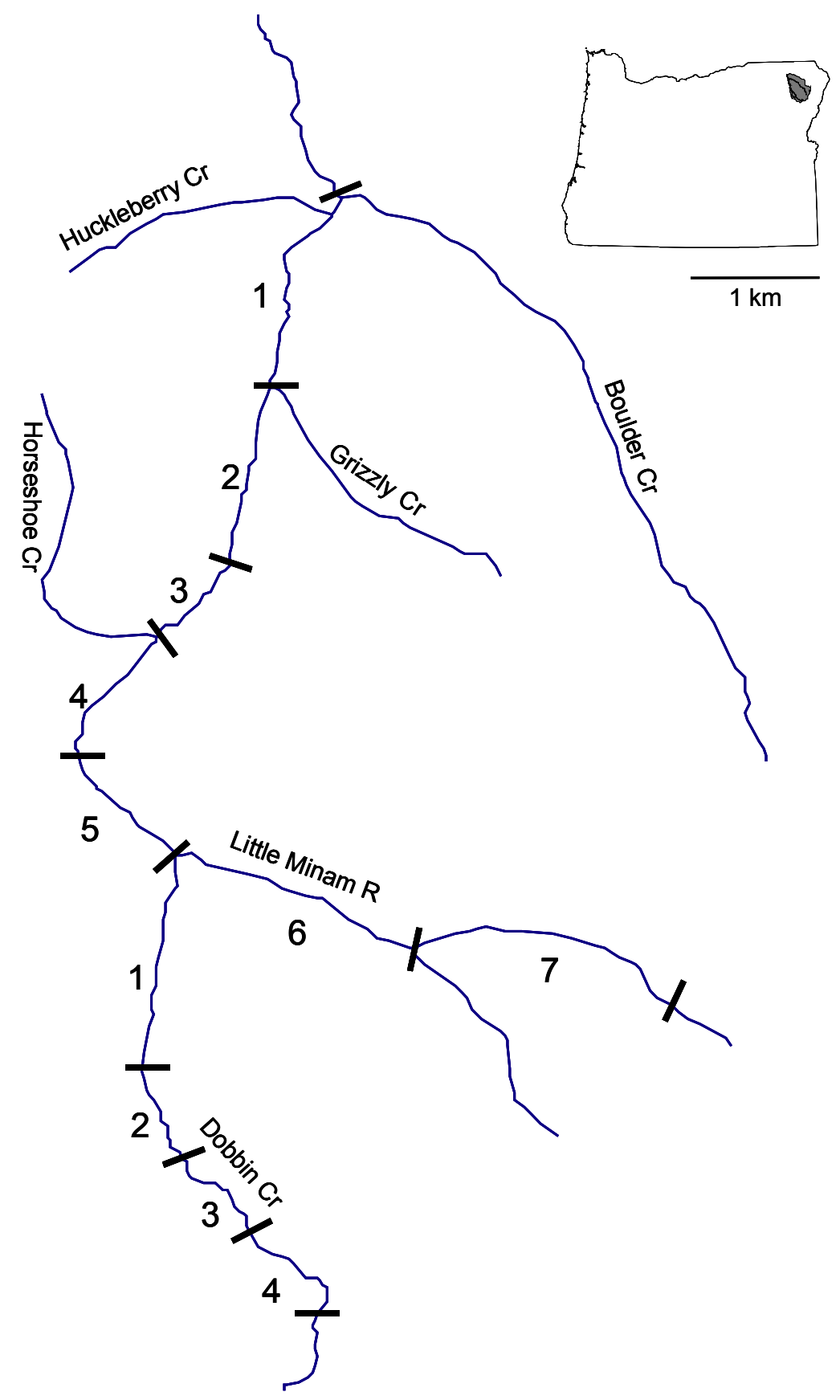

Figure 12. Locations of bull trout spawning survey reaches in Little Minam River and Dobbin Creek. 


\section{Results and Discussion}

We observed 220 bull trout redds in the Mill Creek watershed during 2001. Of these, 163 (74\%) were in Mill Creek and 57 were in tributaries (Fig. 13a). In Mill Creek, 83 redds (51\%) were in reach five, between North Fork Mill Creek and Deadman Creek (Fig. 11). Bull trout redds were not observed in reaches one or three of Mill Creek. We observed only three redds in reach two.
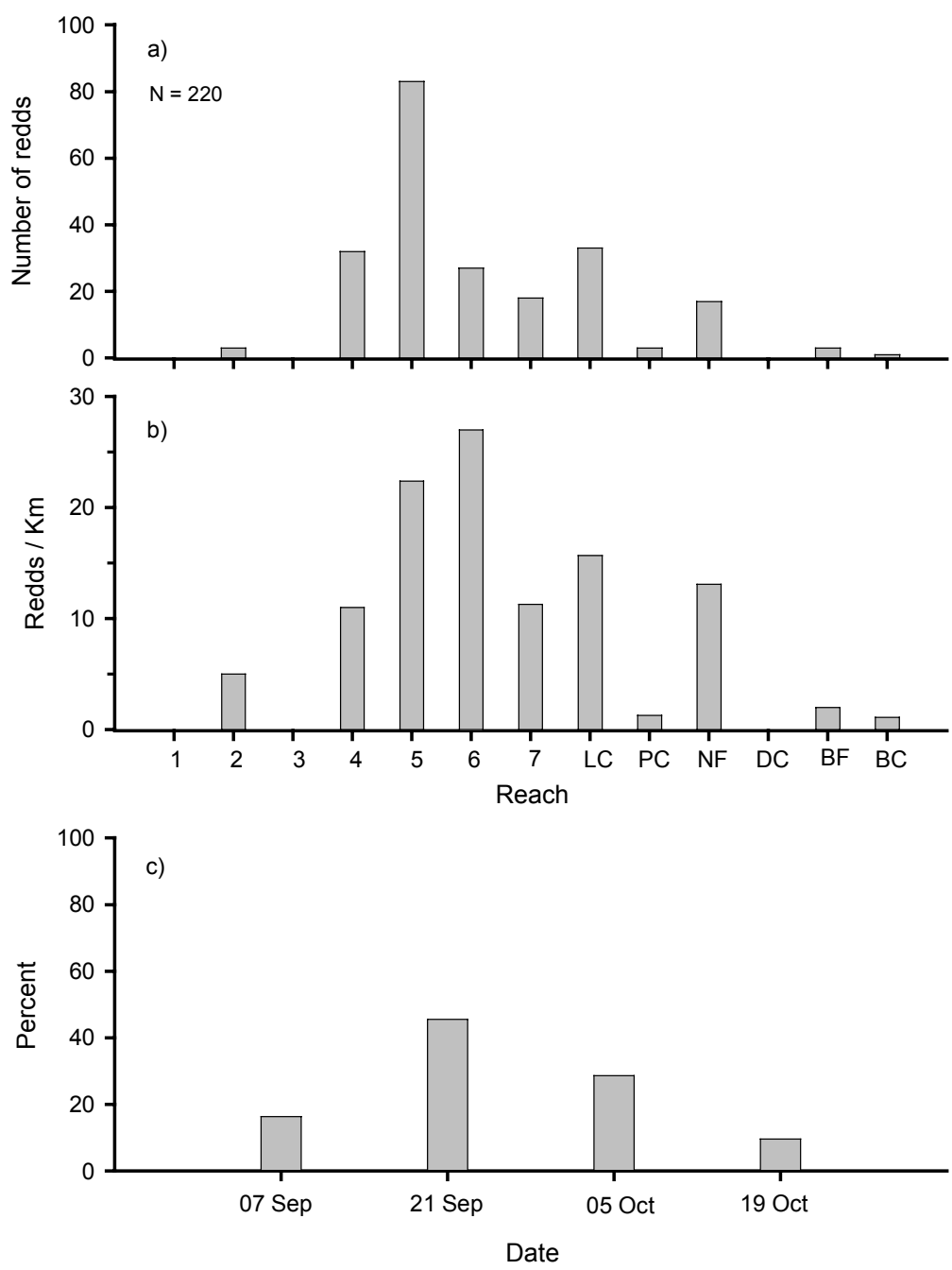

Figure 13. Spawning ground surveys on Mill Creek and tributaries, 2001; a) number and b) density of bull trout redds in each reach, c) proportion of $\mathrm{N}$ observed during each survey. LC = Low Creek, $\mathrm{PC}=$ Paradise Creek, NF $=$ North Fork Mill Creek, DC $=$ Deadman Creek, BF $=$ Burnt Fork and $\mathrm{BC}=$ Bull Creek 
The 57 redds in tributaries amounted to $26 \%$ of the total redds in the watershed. Tributaries contained 27 to $43 \%$ of the total redds during 1996-2000. The percentages of redds in Bull Creek and Burnt Fork Creek in 2001 (2\% and 5\%, respectively) fell within the ranges observed in those tributaries during the five previous years (Bull Creek range $=0-6 \%$ ), and Burnt Fork Creek (range $=5-24 \%$ ). In 2001, 58\% of redds in tributaries were in Low Creek $(n=33)$. Low Creek has contained the most redds observed in all tributaries each year since 1996.

In Mill Creek, the densities ( $\mathrm{n} / \mathrm{km}$ ) of redds ranged from 5 (reach two) to 27 (reach six) (Fig 13b). Based on their large size, we assume most of these redds were made by fluvial bull trout. In Low Creek, there were 18 redds per km. We presently think Low Creek supports primarily resident spawners. While relatively few bull trout had spawned in Mill Creek and tributaries before mid-September, $66 \%$ of all redds observed were counted by late September, and $93 \%$ were counted by 11 October (Fig. 13c).

We observed 432 redds in the Little Minam River watershed in 2001. Of these, 337 were in the Little Minam River and 95 were in Dobbin Creek (Fig. 14a). In the Little Minam River, reaches six and seven both upstream of the confluence with Dobbin Creek (Fig 12), contained 185 redds, or $43 \%$ of the total observed in the watershed. Reaches one, two, three, and five each contained about $6 \%$ of the watershed total.

The 95 redds in Dobbin Creek amounted to $22 \%$ of the watershed total, and nearly half $(n=43)$ of these were in reach one. The total observed in Dobbin Creek this year was substantially more than the number observed any year since 1996. Densities $(\mathrm{n} / \mathrm{km})$ of redds in the Little Minam River ranged from 14 (reaches one and two) to 48 (reach seven), and averaged 26 in the reaches three through six (Fig. 14b). Densities of redds in the four reaches of Dobbin Creek ranged from 11 to 25 . Of all redds observed during 2001, 59\% were counted by mid-September and only $13 \%$ were counted during October (Fig 14c).

The numbers of bull trout redds observed in both watersheds during 2001 were the highest since surveys began (Fig. 15). However, results of surveys in 1994 and 1995 are not directly comparable since these surveys, conducted by the U.S. Forest Service prior to this study, were not as extensive or frequent as surveys since 1996. 

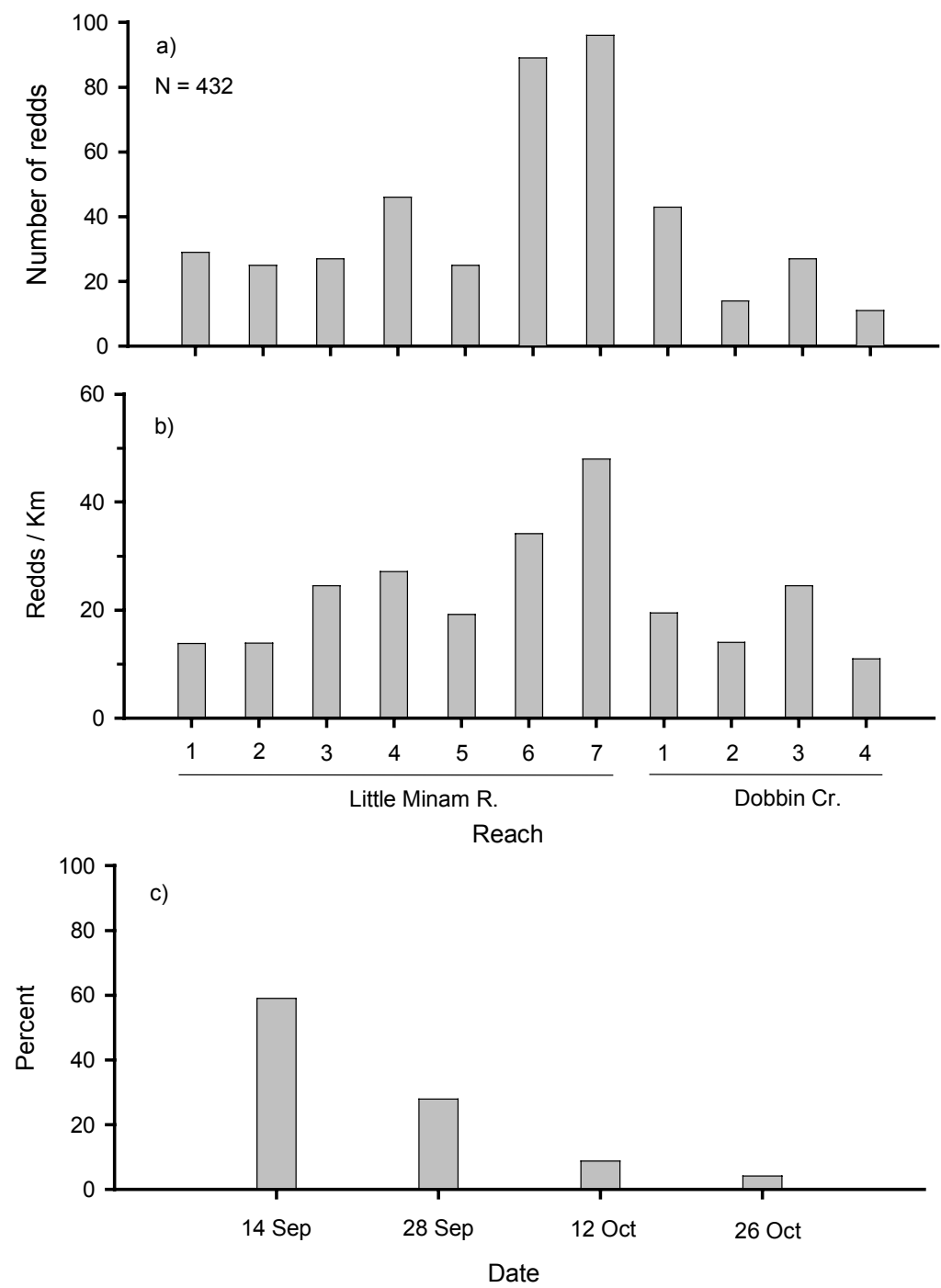

Figure 14. Spawning ground surveys on the Little Minam River and Dobbin Creek, 2001; a) number and b) density of bull trout redds in each reach, c) proportion of $\mathrm{N}$ observed during each survey. 

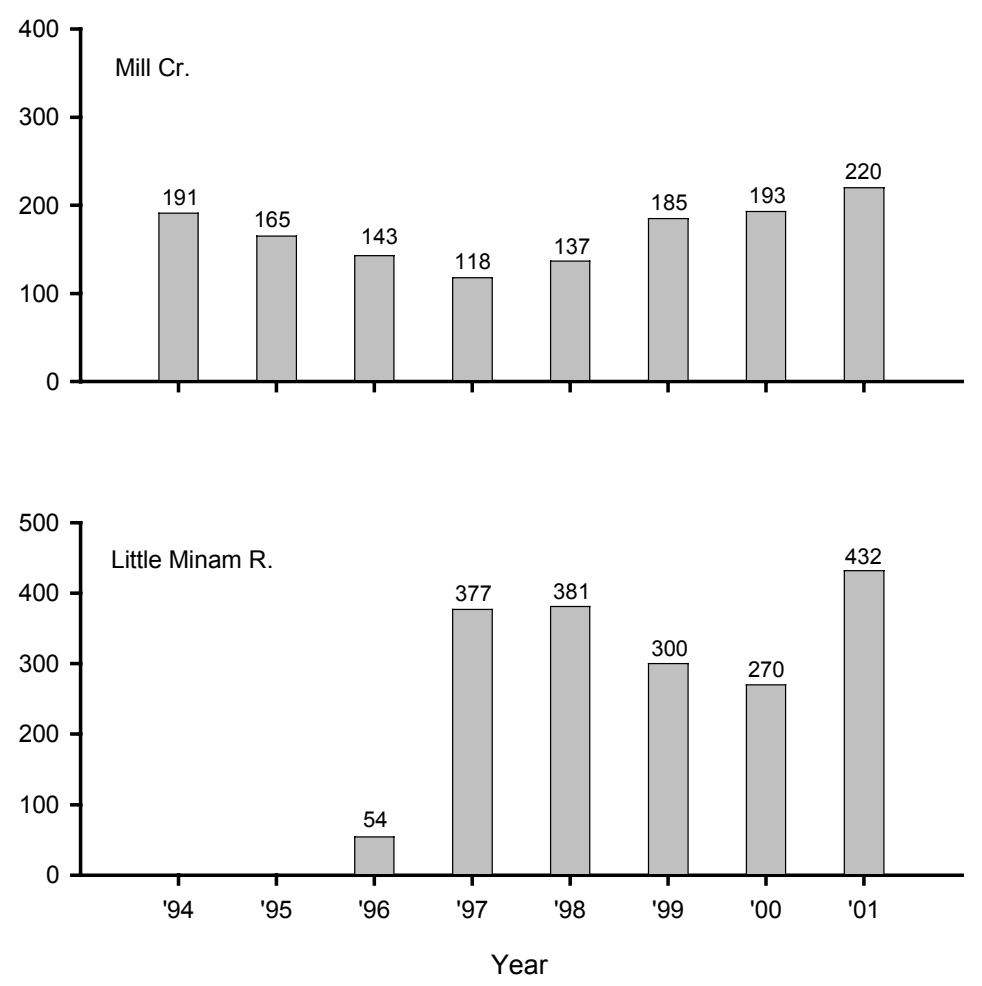

Figure 15. Numbers of bull trout redds observed annually from $1994-2001$. Data from Mill Creek in 1994 and 1995 are courtesy of the USDA Forest Service, Walla Walla, WA. Little Minam River was not surveyed in 1994 and 1995.

In Mill Creek, reach five contained the greatest proportion of redds (range $=31$ to $38 \%$; mean $=34.3 \%$ ) observed annually in the watershed, with the lowest coefficient of variation (cv) which was $9 \%$ among all reaches (Table 7). Although redds in Low Creek tend to be smaller and possibly more difficult to observe than those in reach five of Mill Creek, proportions of redds in Low Creek also had relatively low variation $(\mathrm{cv}=20 \%)$. Together, reach five of Mill Creek and Low Creek produced 48 to $57 \%$ (mean $=52.1 \%$ ) of redds observed annually in the watershed from 1996 through 2001. Expanded numbers of redds counted in reach five and Low Creek differed from observed numbers by less than $3 \%$ in three of six years, and never greater than \pm $9 \%$ (Table 8). 
Table 7. Proportion of bull trout redds observed each year in various survey reaches of Mill Creek and tributaries, and the estimated variation among years.

\begin{tabular}{cccccccccc}
\hline $\begin{array}{c}\text { Survey } \\
\text { reach }\end{array}$ & $\mathbf{1 9 9 6}$ & $\mathbf{1 9 9 7}$ & $\mathbf{1 9 9 8}$ & $\mathbf{1 9 9 9}$ & $\mathbf{2 0 0 0}$ & $\mathbf{2 0 0 1}$ & mean & SD & CV \\
\hline Mill Cr: & & & & & & & & & \\
1 & 0.7 & 0.0 & 0.0 & 0.0 & 0.0 & 0.0 & 0.1 & 0.3 & 245 \\
2 & 0.0 & 0.0 & 0.7 & 0.0 & 0.0 & 1.4 & 0.3 & 0.6 & 165 \\
3 & 0.0 & 4.2 & 2.2 & 2.2 & 1.0 & 0.0 & 1.6 & 1.6 & 102 \\
4 & 16.9 & 11.9 & 10.9 & 20.5 & 6.7 & 14.5 & 13.6 & 4.8 & 36 \\
5 & 37.3 & 30.5 & 32.8 & 31.4 & 36.3 & 37.7 & 34.3 & 3.2 & 9 \\
6 & 7.7 & 12.7 & 10.2 & 7.0 & 5.2 & 12.3 & 9.2 & 3.0 & 33 \\
7 & 2.1 & 13.6 & 12.4 & 7.6 & 7.8 & 8.2 & 8.6 & 4.1 & 47 \\
& & & & & & & & & \\
Low Cr & 12.7 & 16.9 & 19.7 & 22.2 & 20.2 & 15.0 & 18.3 & 3.7 & 20 \\
Paradise & 7.7 & 1.7 & 0.7 & 3.2 & 2.6 & 1.4 & 3.2 & 2.7 & 85 \\
$\quad$ Cr & 4.2 & 2.5 & 4.4 & 3.2 & 8.8 & 7.7 & 4.6 & 2.5 & 53 \\
NF Mill Cr & 4.2 & 0.8 & 2.9 & 0.0 & 3.6 & 0.0 & 1.9 & 1.5 & 78 \\
Deadman & 2.1 & 0.9 & \\
$\quad$ Cr & & & & & & & \\
Burnt Cr & 8.5 & 3.4 & 1.5 & 2.2 & 7.3 & 1.4 & 4.5 & 3.1 & 69 \\
Bull Cr & 0.0 & 1.7 & 1.5 & 0.5 & 0.5 & 0.5 & 0.8 & 0.7 & 84 \\
\hline
\end{tabular}

Table 8. Comparison of total bull trout redds observed and estimated based on redds observed in two survey reaches (Mill Creek reach five and Low Creek).

\begin{tabular}{cccc}
\hline & \multicolumn{2}{c}{ Total redds in watershed } & \\
\cline { 2 - 3 } Year & Observed $(\mathbf{x})$ & Estimated $(\mathbf{y})$ & \% error $^{\mathbf{a}}$ \\
\hline & & & \\
1996 & 142 & 136 & -4.0 \\
1997 & 118 & 107 & -8.9 \\
1998 & 137 & 138 & 0.9 \\
2000 & 185 & 190 & 2.7 \\
2001 & 193 & 209 & 8.4 \\
${ }^{\mathrm{a}}((y-x) / x)^{*} 100$. & 220 & 223 & 1.2 \\
\hline
\end{tabular}


In the Little Minam River, reach seven has produced 21 to $29 \%$ (mean $=24.8 \%$, cv $=11 \%$ ) of redds observed annually in the watershed (Table 9). Using the six-year mean proportion for reach seven, we calculated the estimated number of redds in the Little Minam watershed as we did for Mill Creek. This analysis showed that expansion of the numbers of redds counted in reach seven alone closely estimated the total numbers observed in 1996, 1997 and 1998 (error $=3-5 \%$ ). However, this procedure led to a $15 \%$ over-estimate of the total redds in 2000 as well as 10 and $17 \%$ under-estimates of the total redds in 1999 and 2001, respectively (Table 10). In a second examination for this watershed, we included the numbers of redds counted in reach three of the Little Minam River (cv $=19 \%)$ with those counted in reach seven. Together, these survey reaches produced 29 to $37 \%$ (mean $=32.6 \%$ ) of redds observed annually in the watershed. Compared to reach seven alone, the addition of counts of redds in reach three reduced the magnitude of error in 1996, 1999 and 2000, increased the error in 1997 and 2001, and changed the error in 1998 from positive to negative (Table 10). Using counts of redds in both reaches still produced error of nearly $\pm 15 \%$ in two (2000 and 2001) of six years.

Table 9. Proportion of bull trout redds observed each year in various survey reaches of the Little Minam River and Dobbin Creek, and the estimated variation among years.

\begin{tabular}{cccccccccc}
\hline $\begin{array}{c}\text { Survey } \\
\text { reach }\end{array}$ & $\mathbf{1 9 9 6}$ & $\mathbf{1 9 9 7}$ & $\mathbf{1 9 9 8}$ & $\mathbf{1 9 9 9}$ & $\mathbf{2 0 0 0}$ & $\mathbf{2 0 0 1}$ & mean & SD & CV \\
\hline L. Minam R: & & & & & & & & & \\
1 & 0.0 & 12.2 & 7.9 & 16.3 & 8.9 & 6.7 & 9.1 & 6.1 & 67 \\
2 & 7.4 & 6.6 & 6.6 & 14.0 & 5.2 & 5.8 & 8.0 & 3.5 & 44 \\
3 & 7.4 & 9.3 & 5.8 & 9.3 & 8.9 & 6.3 & 8.1 & 1.5 & 19 \\
4 & 7.4 & 5.0 & 9.7 & 14.3 & 10.7 & 10.6 & 9.4 & 3.5 & 37 \\
5 & 5.6 & 6.1 & 11.3 & 4.7 & 3.3 & 5.8 & 6.2 & 3.0 & 49 \\
6 & 18.5 & 16.2 & 17.1 & 10.0 & 22.2 & 20.6 & 16.8 & 4.5 & 26 \\
7 & 25.9 & 25.7 & 25.7 & 20.7 & 28.5 & 22.2 & 25.3 & 2.9 & 11 \\
Dobbin Cr: & & & & & & & & & \\
1 & 22.2 & 11.7 & 3.9 & 3.3 & 8.9 & 10.0 & 10.0 & 7.7 & 77 \\
2 & 5.6 & 1.6 & 2.4 & 2.0 & 0.0 & 3.2 & 2.3 & 2.0 & 88 \\
$3-4$ & 0.0 & 5.6 & 9.7 & 5.3 & 3.3 & 8.8 & 4.8 & 3.5 & 74 \\
\hline
\end{tabular}


Table 10. Comparison of total bull trout redds observed and estimated based on redds observed in selected survey reaches in the Little Minam River watershed.

\begin{tabular}{|c|c|c|c|}
\hline \multirow{2}{*}{$\begin{array}{l}\text { Reach, } \\
\text { Year }\end{array}$} & \multicolumn{2}{|c|}{ Total redds } & \multirow[b]{2}{*}{$\%$ error $^{a}$} \\
\hline & Observed (x) & Estimated (y) & \\
\hline \multicolumn{4}{|l|}{ Reach 7: } \\
\hline 1996 & 54 & 56 & 4.5 \\
\hline 1997 & 377 & 391 & 3.8 \\
\hline 1998 & 381 & 395 & 3.7 \\
\hline 1999 & 300 & 250 & -16.7 \\
\hline 2000 & 270 & 310 & 15.0 \\
\hline 2001 & 432 & 387 & -10.4 \\
\hline \multicolumn{4}{|l|}{ Reaches 7 and 3: } \\
\hline 1996 & 54 & 55 & 2.3 \\
\hline 1997 & 377 & 405 & 7.4 \\
\hline 1998 & 381 & 368 & -3.4 \\
\hline 1999 & 300 & 276 & -8.0 \\
\hline 2000 & 270 & 310 & 14.8 \\
\hline 2001 & 432 & 377 & -12.7 \\
\hline
\end{tabular}

Results presented here indicate that numbers of bull trout redds in selected stream reaches can correlate with the total number of redds with relatively small error $( \pm 9 \%)$ in the Mill Creek watershed. Depending on the objectives of spawning surveys, this precision may be acceptable in lieu of the effort required for annual surveys of entire spawning areas in a watershed. We emphasize that the identification of such reaches required systematic surveys throughout all spawning areas in both watersheds, conducted four times annually for six years. We also do not know how well counts in these reaches correspond with total counts in years with more widely ranging abundances. However, results of similar efforts in the Little Minam River watershed indicated that error in estimation could range from -13 to $+15 \%$. This level of precision may or may not be acceptable depending on objectives and desired levels of precision. 


\section{Acknowledgments}

This project is grateful to L. Boe with the US Forest Service, Walla Walla Ranger District for assistance with trapping, telemetry and spawning surveys in Mill Creek. We thank S. Starcevich for assistance with collection of temperature data loggers. We appreciate the assistance with spawning surveys in the Grande Ronde basin provided by J. Zakel and T. Walters. Finally, we thank the Oregon State Police for successful telemetry flights.

\section{References cited}

Bonneau, ,J.L., R.F. Thurow, and D.L. Scarnecchia. 1995. Capture, marking, and enumeration of juvenile bull trout and cutthroat trout in small, low-conductivity streams. North American Journal of Fisheries Management, 15:563-568.

Buchanan, D. V. and S. V. Gregory. 1997. Development of water temperature standards to protect and restore habitat for bull trout and other cold water species in Oregon. Pages 119-126 in Mackay, W. C., M. K. Brewin, and M. Monita, editors. Friends of the bull trout conference proceedings. Bull trout task force (Alberta), C/O Trout Unlimited Canada, Calgary.

Buchanan, D.V., M. Hanson and B. Hooton. 1997. Bull trout status report for Oregon. Oregon Department of Fish and Wildlife. Portland, OR.

Dunham, J. and B. Rieman. 1999. Metapopulation structure of bull trout: influences of habitat size, isolation, and human disturbance. Ecological Applications 9 (2): 642-655.

Fraley, J. J. and B. B. Shepard. 1989. Life history, ecology, and population status of migratory bull trout (Salvelinus confluentus) in the Flathead Lake river system, Montana. Northwest Science 63 (4): 133-143.

Gamett, B. L. 2002. The relationship between water temperature and bull trout distribution and abundance. M. S. Thesis. Utah State University, Logan.

Hemmingsen, A. R., D. V. Buchanan, and P. J. Howell. 1996. Bull trout life history, genetics, habitat needs, and limiting factors in central and northeast Oregon, 1995 Annual Report. Project Number 199405400, Bonneville Power Administration, Portland, Oregon.

Hemmingsen, A. R., B. L. Bellerud, D. V. Buchanan, S. L. Gunckel, J. S. Shappart, and P. J. Howell. 2001. Bull trout life history, genetics, habitat needs, and limiting factors in central and northeast Oregon, 1997 Annual Report. Project Number 199405400, Bonneville Power Administration, Portland, Oregon.

Hemmingsen, A. R., B. L. Bellerud, S. L. Gunckel, and P. J. Howell. 2001. Bull trout life history, genetics, habitat needs, and limiting factors in central and northeast Oregon, 1998 Annual Report. Project Number 199405400, Bonneville Power Administration, Portland, Oregon. 
Hemmingsen, A. R., S. L. Gunckel and P. J. Howell. 2001. Bull trout life history, genetics, habitat needs, and limiting factors in central and northeast Oregon, 1999 Annual Report. Project Number 199405400, Bonneville Power Administration, Portland, Oregon.

Hemmingsen, A. R., S. L. Gunckel, P.M. Sankovich, and P. J. Howell. 2001. Bull trout life history, genetics, habitat needs, and limiting factors in central and northeast Oregon, 2000 Annual Report. Project Number 199405400, Bonneville Power Administration, Portland, Oregon.

Hillman, T.C., J.W. Mullan, and J.S. Griffith. 1992. Accuracy of underwater counts of juvenile chinook salmon, coho salmon, and steelhead. North American Journal of Fisheries Management, 12:598-603.

Maxell, B. A. 1999. A prospective power analysis on the monitoring of bull trout stocks using redd counts. North American Journal of Fisheries Management 19:860-866.

Meffe, G.K. and C.R. Carroll. 1994. Principles of conservation biology. Sinauer, Sunderland, MA.

Reiman, B.E. and G.L. Chandler. 1999. Empirical evaluation of temperature effects on bull trout distribution in the Northwest. Final repot to Environmental Protection Agency, Boise, Idaho.

Rieman, B.E. and J.D. Mclntyre. 1993. Demographic and habitat requirements for conservation of bull trout. General Technical Report INT-302, Intermountain Research Station, Ogden, UT.

Rieman, B.E. and D.L. Myers. 1997. Use of redd counts to detect trends in bull trout (Salvelinus confluentus) populations. Conservation Biology 11(4): 1015-1018.

Selong, J. H., T. E. McMahon, A. V. Zale, and F. T. Barrows. 2001. Effect of temperature on growth and survival of bull trout, with application of an improved method for determining thermal tolerance in fishes. Transactions of the American Fisheries Society 130:10261037.

Thurow, R.F. and D.J. Schill. 1996. Comparison of day snorkeling, night snorkeling, and electrofishing to estimate bull trout abundance and size structure in a second-order Idaho stream. North American Journal of Fisheries Management, 16:314-323. 